\title{
Development of Novel Potential Pleiotropic Compounds of Interest in Alzheimer's Disease Treatment through Rigidification Strategy
}

\author{
Cédric Lecoutey, Rémi Legay, Audrey Davis $\mathbb{D}$, Jana Sopková-de Oliveira Santos, Patrick Dallemagne *(i) \\ and Christophe Rochais * $\mathbb{D}$
}

Normandie Univ, Unicaen, Cermn, 14000 Caen, France; cedric.lecoutey@unicaen.fr (C.L.); remi.legay@unicaen.fr (R.L.); audrey.davis@unicaen.fr (A.D.); jana.sopkova@unicaen.fr (J.S.-d.O.S.)

* Correspondence: patrick.dallemagne@unicaen.fr (P.D.); christophe.rochais@unicaen.fr (C.R.); Tel.: +33-2-31-56-68-13 (P.D. \& C.R.)

check for updates

Citation: Lecoutey, C.; Legay, R.; Davis, A.; Sopková-de Oliveira Santos, J.; Dallemagne, P.; Rochais, C. Development of Novel Potential Pleiotropic Compounds of Interest in Alzheimer's Disease Treatment through Rigidification Strategy. Molecules 2021, 26, 2536. https://doi.org/10.3390/ molecules26092536

Academic Editors: Fernanda Borges, Sofia Benfeito, Daniel Chavarria, Pedro Soares and Andrea Trabocchi

Received: 26 February 2021

Accepted: 20 April 2021

Published: 26 April 2021

Publisher's Note: MDPI stays neutral with regard to jurisdictional claims in published maps and institutional affiliations.

Copyright: (c) 2021 by the authors. Licensee MDPI, Basel, Switzerland. This article is an open access article distributed under the terms and conditions of the Creative Commons Attribution (CC BY) license (https:/ / creativecommons.org/licenses/by/ $4.0 /)$.

\begin{abstract}
The development of Multi-Target Directed Ligand is of clear interest for the treatment of multifactorial pathology such as Alzheimer's disease (AD). In this context, acetylcholinesterase $(\mathrm{AChE})$ inhibitors have been modulated in order to generate novel pleiotropic compounds targeting a second protein of therapeutic interest in AD. Among them, donecopride was the first example of a dual acetylcholinesterase inhibitor and $5-\mathrm{HT}_{4}$ receptor agonist. In order to explore the structural diversity around this preclinical candidate we have explored the preparation of novel constrained analogs through late-stage rigidification strategy. A series of phenylpyrazoles was prepared in a late-stage functionalization process and all compounds were evaluated in vitro towards AChE and 5-HTRs. A docking study was performed in order to better explain the observed SAR towards $\mathrm{AChE}, 5-\mathrm{HT}_{4} \mathrm{R}$ and $5-\mathrm{HT}_{6} \mathrm{R}$ and this study led to the description of novel ligand targeting both AChE and $5-\mathrm{HT}_{6} \mathrm{R}$.
\end{abstract}

Keywords: Alzheimer's disease; acetylcholinesterase; 5-HT 6 R; donecopride; MTDL

\section{Introduction}

In the field of neurodegenerative diseases, the prototype of multifactorial pathologies, the development of Multi-Target Directed Ligands (MTDLs) offered great promise and therapeutic opportunities [1]. Indeed, these compounds are rationally designed to display multiple activities by modulating several biological targets of interest in the treatment of a specific disease. Chosen to demonstrate a therapeutic synergy, the association of these biological targets needs to be rigorously determined [2]. In the field of Alzheimer's disease (AD), multiple in vitro or in vivo MTDL candidates have been generated over the last years and could lead to preclinical or clinical opportunities [3]. Because of its validated interest in the treatment of AD symptoms, acetylcholinesterase (AChE) inhibitors, such as donepezil, have been chosen as a starting point to develop novel analogs with a second biological target such as receptors [4]. As an example, we recently described the preclinical candidate donecopride, the first MTDL able to demonstrate AChE inhibition and activating serotoninergic receptors 5- $\mathrm{HT}_{4}$ (Figure 1) [5-7].

This secondary target was chosen because of the ability of $5-\mathrm{HT}_{4} \mathrm{R}$ agonists to favor the "non-amyloidogenic" cleavage of the amyloid precursor protein (APP) by $\alpha$-secretase, inducing then a decrease in amyloid pathology. [8] This positive effect has already been demonstrated with the use of RS67333 a reference 5- $\mathrm{HT}_{4} \mathrm{R}$ agonist, in primary neurons, [9] and led to the in vivo improvement of memory in several animal models of AD [10]. Indeed, in the context of $\mathrm{AD}$, the activation of $5-\mathrm{HT}_{4} \mathrm{Rs}$ with agonist has led to the increase in neurotransmitter release as well as a clear impact of amyloid load in transgenic mice models after chronic administration. Several $5-\mathrm{HT}_{4} \mathrm{R}$ agonists have been studied in clinical 
trials in recent years to demonstrate both symptomatic and disease-modifying effect against $\mathrm{AD}$ [11]. Beside this receptor subtypes, other serotonin receptors have been studied in the field of neurodegenerative diseases [12], such as the $5-\mathrm{HT}_{6} \mathrm{R}[13,14]$. Specifically, $5-\mathrm{HT}_{6} \mathrm{R}$ antagonists increase extracellular levels of acetylcholine, glutamate, and norepinephrine in forebrain regions, whereas activation of $5-\mathrm{HT}_{6} \mathrm{R}$ inhibits corticostriatal glutamatergic transmission. In the end, these various elements (notably, distribution in limbic areas, modulation of different systems of neurotransmission) are in favor of the implication of $5-\mathrm{HT}_{6} \mathrm{R}$ in the modulation of the cognitive processes as well as mood regulation and of numerous behaviors (eating behavior, addictive behavior, etc.). Indeed, they appear as a valuable target to treat cognitive impairments since their blockade confers to 5-HT $\mathrm{H}_{6} \mathrm{R}$ antagonists', such as idalopirdine (Figure 1), procognitive effects. [15] It is important to note that during the clinical trials the potential synergistic effect to act simultaneously on $5-\mathrm{HT}_{6} \mathrm{R}$ and $\mathrm{AChE}$ has been evaluated since idalopirdine has been tested along with donepezil [16].
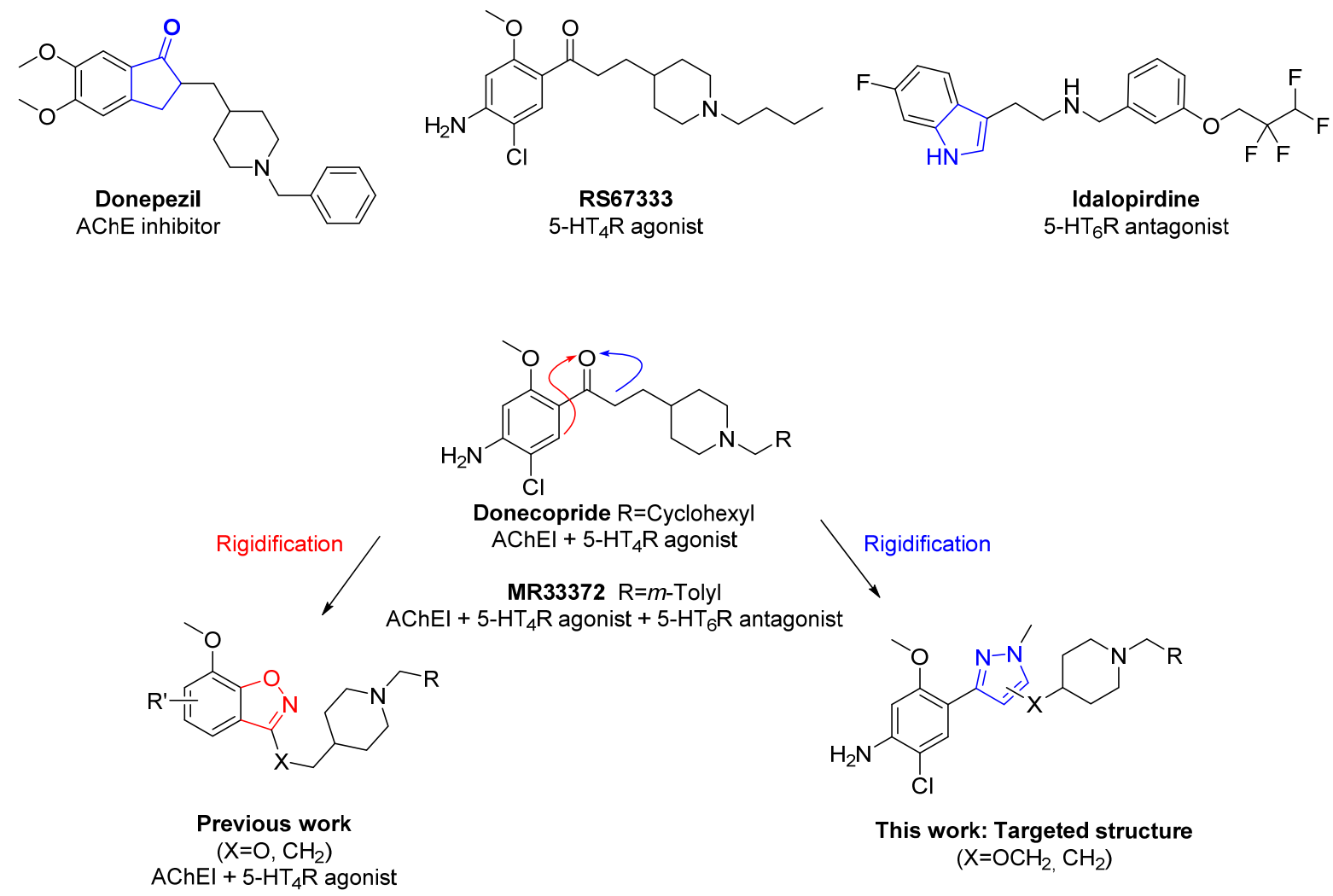

Figure 1. Structures of reference ligands and MTDL (Donecopride, MR33372, benzisoxazole) and targeted structure.

In this context, we recently described initial modulations of donecopride by introducing a series of substituent on the piperidine ring, which yielded the description of a first 5- $\mathrm{HT}_{4} \mathrm{R}$ agonist and 5- $\mathrm{HT}_{6} \mathrm{R}$ antagonist, [17] and MR33372, the first compound able to modulate simultaneously $\mathrm{AChE}, 5-\mathrm{HT}_{4} \mathrm{R}$ and $5-\mathrm{HT}_{6} \mathrm{R}$ [18]. In parallel with these first works, we also decided to assess the impact of conformational restriction on the aromatic ring, inspired by both bicyclic donepezil and idalopirdine (Figure 1). Indeed, such restriction are classical in drug discovery [19], and we recently described the preparation and biological evaluation of benzisoxazole analog possessing an oxygen or a methylene linker [20]. We would like to describe in this article, a novel rigidification strategy with the construction of a novel heterocycle between the ketone and its alpha-position. The preparation of novel phenylpyrazole derivatives possessing either a methylene or an oxygen linker (Figure 1), as well as their biological evaluation against $\mathrm{AChE}$ and both $5-\mathrm{HT}_{4} \mathrm{R}$ and $5-\mathrm{HT}_{6} \mathrm{R}$ will be described and compared with other members of this series. 


\section{Results}

\subsection{Chemistry}

The access to targeted compounds was achieved starting from Boc-protected benzophenone 1 that we previously described (Scheme 1) [5]. The latter was treated by DMF-DMA [21] to generate an intermediate dimethyl enamines, which was not isolated, but reacted in boiling ethanol with methylhydrazine to generate the expected pyrazole 2 with $38 \%$ yield $[22,23]$. In order to obtain the final derivatives, the Boc protecting group was removed with TFA, and the resulted piperidine was alkylated with the appropriate bromide to generate the final cyclohexyl and $m$-tolyl substituted analog $3 \mathbf{a}-\mathbf{b}$. These particular substituents were chosen for a better comparison with either donecopride and MR33372. In order to verify the impact of the aniline both on the reactivity and the biological activities, the corresponding acetamides $\mathbf{4} \mathbf{5}$ were obtained in acetic anhydride with good yields. Following the same procedure, the cyclohexyl substituted analogs 6 and 7 were prepared after deprotection and alkylation (Scheme 1).

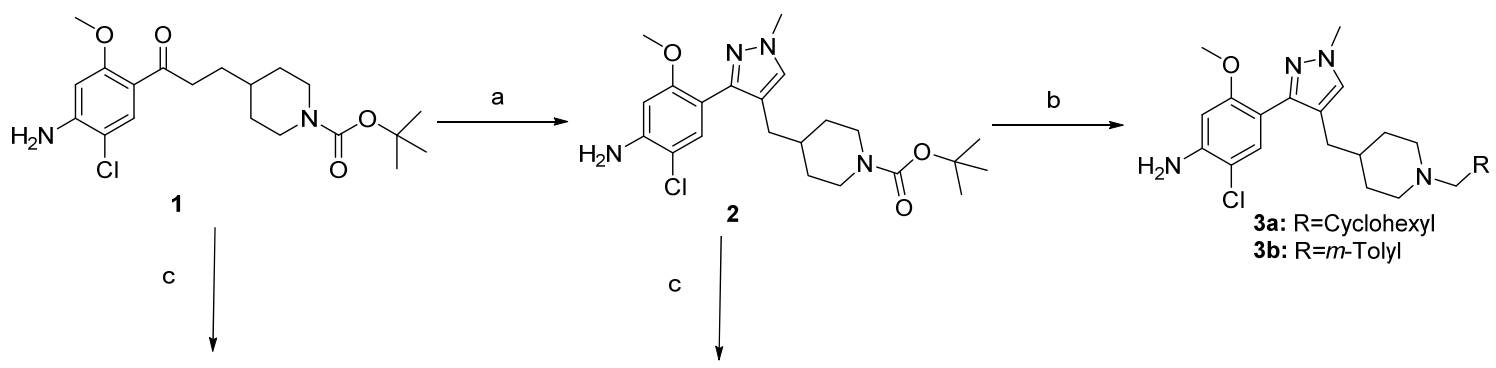<smiles>COc1cc(NC(C)=O)c(Cl)cc1C(=O)CCC1CCN(C(=O)OC(C)(C)C)CC1</smiles>

4 b<smiles>COc1cc(NC(C)=O)c(Cl)cc1C(=O)CCC1CCN(CC2CCCCC2)CC1</smiles><smiles>CCC(C)(C)OC(=O)N1CCC(Cc2cn(C)nc2-c2cc(Cl)c(NC(C)=O)cc2OC)CC1</smiles>

Scheme 1. Synthetic pathways for access to compounds 2-7. Reagents and conditions: (a) i. DMF.DMA, Rflx, ii. $\mathrm{CH}_{3} \mathrm{NHNH}_{2}, \mathrm{EtOH}, \mathrm{Rflx}, \mathrm{mw}, 38 \%$; (b) i. TFA, DCM, TA, ii. $\mathrm{RCH}_{2} \mathrm{Br}, \mathrm{K}_{2} \mathrm{CO}_{3}, \mathrm{DMF}$, or acetone, $110{ }^{\circ} \mathrm{C}, 31-46 \%$; (c) $\mathrm{Ac}_{2} \mathrm{O}, \mathrm{rt}, 24 \mathrm{~h}, 78-83 \%$.

As already described in the benzisoxazole [20] and donecopride series [6], the influence of the linker could be of great importance on the ability of the ligand to bind to AChE. We then investigated the possibility to modulate both the linker and its position on the pyrazole ring. Indeed, the $\beta$-ketoester 8 is a crucial intermediate in the preparation of the benzophenone $\mathbf{1}$ and was then already available [6]. Afterwards, 8 was treated with methylhydrazine in refluxing ethanol to obtain the pyrazolone 9 a with $57 \%$ yield (Scheme 2). Unfortunately, the O-alkylation procedure tested was ineffective to generate the expected piperidine 10a, due to the reactivity of the aniline moiety. The pyrazolone $9 \mathrm{a}$ was then treated with acetic anhydride to obtain the ester $\mathbf{1 1}$ with $94 \%$ yield, before being hydrolyzed with $\mathrm{LiOH}$ to generate the acetamide $9 \mathrm{~b}$. The latter was then alkylated with $\mathrm{N}$-Boc 4-iodomethylpiperidine in DMF to generate this time the expected ether $\mathbf{1 0 b}$ with good conversion. Finally, the protecting group was removed with trifluoroacetic acid, and the $m$-tolyl analog $\mathbf{1 2} \mathbf{b}$ was obtained after an $N$-alkylation reaction with the corresponding 
bromide. Unfortunately, all attempts aiming at deprotecting the $N$-acetamide group of $\mathbf{1 2 b}$ failed. In order to verify this time the impact of the substitution of the aromatic ring, commercial pyrazolone $\mathbf{9} \mathbf{c}-\mathbf{d}$ were engaged in the same procedure. The 3-4-dimethoxyphenyl group of $9 \mathbf{d}$ was chosen by analogy with donepezil, a reference AChE inhibitor (AChEI). The expected $m$-tolyl analogs $\mathbf{1 2 c}-\mathbf{d}$ were obtained in a two-step synthesis.<smiles>[R]C(C)(C)C(=O)CC(=O)OCC</smiles><smiles>COc1cc(NC(C)=O)c(Cl)cc1-c1cc(OC(C)=O)n(C)n1</smiles><smiles>[R]c1ccc(C2=NN(C)C(=O)C2)cc1-c1cc(OCC2CCN(C(=O)OC(C)(C)CC)CC2)n(C)n1</smiles>

Scheme 2. Synthesis pathways for access to compounds 9-12. Reagents and conditions: (a) $\mathrm{CH}_{3} \mathrm{NHNH}_{2}, \mathrm{EtOH}, 160{ }^{\circ} \mathrm{C}$, mw, 57\%; (b) N-Boc 4-iodomethylpiperidine, $\mathrm{K}_{2} \mathrm{CO}_{3}, \mathrm{DMF}, 60{ }^{\circ} \mathrm{C}, 21-27 \%$; (c) $\mathrm{Ac}_{2} \mathrm{O}, 94 \%$, (d) $\mathrm{LiOH}, \mathrm{EtOH} / \mathrm{H}_{2} \mathrm{O}, \mathrm{Rfx}, 76 \%$, (e) i. TFA, DCM, TA, ii. $m$-TolylCH${ }_{2} \mathrm{Br}, \mathrm{K}_{2} \mathrm{CO}_{3}$, acetone, $110{ }^{\circ} \mathrm{C}, 32-67 \%$.

\subsection{In Vitro Results}

The inhibitory activity of novel analogs towards $h \mathrm{AChE}$ was evaluated according to the Ellman test [24]. Their affinity for human $5-\mathrm{HT}_{4} \mathrm{R}$ and $5-\mathrm{HT}_{6} \mathrm{R}$ was assessed using a radioligand displacement assay (Table 1). In these tests, donepezil (DPZ) was used as a reference AChEI, RS67333 as a 5- $\mathrm{HT}_{4} \mathrm{R}$ ligand, and idalopirdine as a $5-\mathrm{HT}_{6} \mathrm{R}$ ligand, respectively.

As already introduced, we demonstrated that pharmacomodulation of the preclinical candidate donecopride could greatly affect the ability of its analog to interact with ChE and 5-HT receptors. Indeed, in our initial study [6], we showed that its ester or amide analogs lose their ability to inhibit AChE. The same tendency has also been observed in the benzisoxazole family with a clear impact of the modulation of the benzenic position on both $\mathrm{AChE}$ and 5- $\mathrm{HT}_{4} \mathrm{R}$ binding. [20] In this context, we decided to explore the modulation of the $\alpha$-position of the ketone and the possibility to generate conformationally constrained derivatives to increase the elucidation of SAR around donecopride. The preparation of first series of phenylpyrazoles $\mathbf{3} \mathbf{a}-\mathbf{b}$ and $\mathbf{6}$, was then achieved from the advance intermediate 1. In this synthesis, the protection of the basic nitrogen with a Boc group is mandatory to obtain the pyrazole cycle, since all attempts to modulate the final donecopride analog in a late stage process failed. For this reason, we also explored in parallel the impact of the 
protection of the aniline moiety with an acetamide group, with no clear benefit in terms of synthesis of compound $\mathbf{6}$. The preparation of the Boc protected $\mathbf{2}$ was, however, of interest since it allowed us to introduce in a convergent way both the cyclohexyl and the $m$-tolyl moieties. Indeed if the cyclohexyl present in donecopride yielded low nanomolar affinities for both $\mathrm{AChE}$ and $5-\mathrm{HT}_{4} \mathrm{R},[6]$ its replacement by a $m$-tolyl generated triple activity this time towards 5- $\mathrm{HT}_{6} \mathrm{R}$ [18]. If MR33372 possesses affinities in the hundred $\mathrm{nM}$ range for the three targets, this compound demonstrated an in vivo anti-amnesic effect in a model of scopolamine induced deficit.

Table 1. hAChE inhibitory activity and affinity for $5-\mathrm{HT}_{4} \mathrm{R}$ and $5-\mathrm{HT}_{6} \mathrm{R}$.

\begin{tabular}{|c|c|c|c|c|c|c|}
\hline \multirow[b]{2}{*}{ Compound } & \multicolumn{2}{|c|}{$h \mathrm{AChE}$} & \multicolumn{2}{|c|}{$h 5-\mathrm{HT}_{4} \mathrm{R}$} & \multicolumn{2}{|c|}{$h 5-\mathrm{HT}_{6} \mathrm{R}$} \\
\hline & $\begin{array}{c}\% \text { Inhibition at } \\
10^{-6} \mathrm{M}\end{array}$ & $\begin{array}{c}\mathrm{IC}_{50}(\mathrm{nM}) \\
\quad(n=3)\end{array}$ & $\begin{array}{c}\% \text { Inhibition at } \\
10^{-6} \mathrm{M}\end{array}$ & $\begin{array}{c}\mathrm{K} i(\mathrm{nM}) \\
(n=3)\end{array}$ & $\begin{array}{c}\% \text { Inhibition at } \\
10^{-6} \mathrm{M}\end{array}$ & $\mathrm{K} i(\mathrm{nM})(n=3)$ \\
\hline Donepezil & $98 \%$ & $7.7 \pm 1.3$ & - & - & - & - \\
\hline RS67333 & - & - & 100 & $5.1 \pm 0.51$ & - & - \\
\hline Idalopirdine & - & - & - & - & 106 & $7.05 \pm 0.61$ \\
\hline Donecopride & $96 \%$ & $16 \pm 5$ & $100 \%$ & $7.05 \pm 0.61$ & $30 \%$ & ND \\
\hline MR33372 & $89 \%$ & $\begin{array}{c}(16 \pm 4) \times \\
10\end{array}$ & $98 \%$ & $(17 \pm 1) \times 10$ & $80 \%$ & $(23 \pm 5) \times 10$ \\
\hline 7 & $98 \%$ & $34 \pm 5$ & $94 \%$ & $(3 \pm 1) \times 10^{2}$ & - & ND \\
\hline $3 a$ & $34 \%$ & ND & $34 \%$ & ND & $2 \%$ & ND \\
\hline $3 b$ & $76 \%$ & $110 \pm 4$ & $20 \%$ & ND & $68 \%$ & $(47 \pm 9) \times 10$ \\
\hline 6 & $31 \%$ & ND & $16 \%$ & ND & $0 \%$ & ND \\
\hline $12 b$ & $15 \%$ & ND & $9 \%$ & ND & $0 \%$ & ND \\
\hline $12 c$ & $15 \%$ & ND & $10 \%$ & ND & $6 \%$ & ND \\
\hline $12 d$ & $6 \%$ & ND & $9 \%$ & ND & $9 \%$ & ND \\
\hline
\end{tabular}

$\mathrm{IC}_{50}$ and $\mathrm{K} i$ values are expressed as mean \pm standard error of the mean (SEM) of three experiments; ND: not determined.

Compared with donecopride, the introduction of the acetamide group on 7 had little impact on $\mathrm{AChE}$ inhibition ( $\mathrm{IC}_{50}=16 \mathrm{vs}$. $34 \mathrm{nM}$ respectively), but greatly affected the affinity for $5-\mathrm{HT}_{4} \mathrm{R}$ (Table 1 ). The introduction of the methylpyrazole ring on $3 \mathrm{a}$ led to a complete loss of activities for all targets. Interestingly, however, the introduction of the $m$-tolyl moiety is again of interest for $\mathbf{3 b}$. Compared to MR33372 this time, $\mathbf{3 b}$ is a slightly better AChEI ( $\mathrm{IC}_{50}=161 \mathrm{vs.} 111 \mathrm{nM}$ respectively) and possesses a decreased affinity for $5-\mathrm{HT}_{6} \mathrm{R}$. Contrary, the conformational restriction greatly affects the ability of the compound to bind to $5-\mathrm{HT}_{4} \mathrm{R}$. Due to its synthetic accessibility from intermediate $\mathbf{8}$, a second series of ether substituted analog $\mathbf{1 2 b} \mathbf{b} \mathbf{d}$ was generated bearing the $m$-tolyl substituent previously identified. Unfortunately, this modulation led to a complete loss of activities for the three targets.

\subsection{In Silico Results}

In order to better understand the impact of these SAR on AChE binding, a docking study was performed with $\mathbf{3 b}$ in comparison with donecopride (Figure 2). The docking study was carried out with the aim to predict the AChE inhibition of synthesized compounds compared to donecopride, the initial scaffold of the carried out modulations. The docking study into the $h \mathrm{AChE}$ active site (PDB code: 4EY7) [25] was performed using Gold 5.7.2 software and the ligand 3D models were built from donecopride $X$-ray structure solved previously. Firstly, the correctness of employed docking procedure was checked by redocking the co-crystallized ligand, donepezil. Gold program regained the crystallographic donepezil position with a RMSD smaller to $1 \AA$ and with a score fit value of 110.02 [6]. Next, the docking procedure was applied to donecopride and to the newly synthesized compounds ( $3 \mathbf{b}, \mathbf{7}$, and $\mathbf{1 2 b}$ ). The docking generated positions closed to donepezil one for donecopride (score fit 105.14, Figure 2) and for compound 7 (score fit $\sim 117.63$, Figure 2) and 12b (score fit 86.79 , Figure 2). Indeed, donecopride and compound 7 under the docking results reproduces well the donepezil key binding interactions: (i) the 
charged nitrogen of the piperidine ring is oriented in a position suitable for an Hbond with the water molecule in the proximity of $\mathrm{Tyr}_{337}$ and $\mathrm{Tyr}_{341}$, (ii) the carbonyl group of both ligands forms an Hbond with $\mathrm{NH}$ of the Phe 295 backbone, (iii) the benzene ring is positioned in a parallel way to the $\operatorname{Trp}_{286}$ indole ring to favor the $\pi$-stacking interaction and (iv) the cyclohexane ring occupied the donepezil benzyl ring place in neighboring of $\operatorname{Trp}_{86}$. Even if compound $\mathbf{1 2 b}$ was positioned systematically with the substituted phenyl ring towards the binding cavity's bottom, its position was higher comparing to previous three compounds. Consequently, $\mathbf{1 2 b}$ lost, more to the loss of Hbond due to carbonyl group absence in its scaffold, also the interaction through the piperidine's protonated nitrogen as well as $\pi$-stacking with $\operatorname{Trp}_{86}$ (Figure 2).
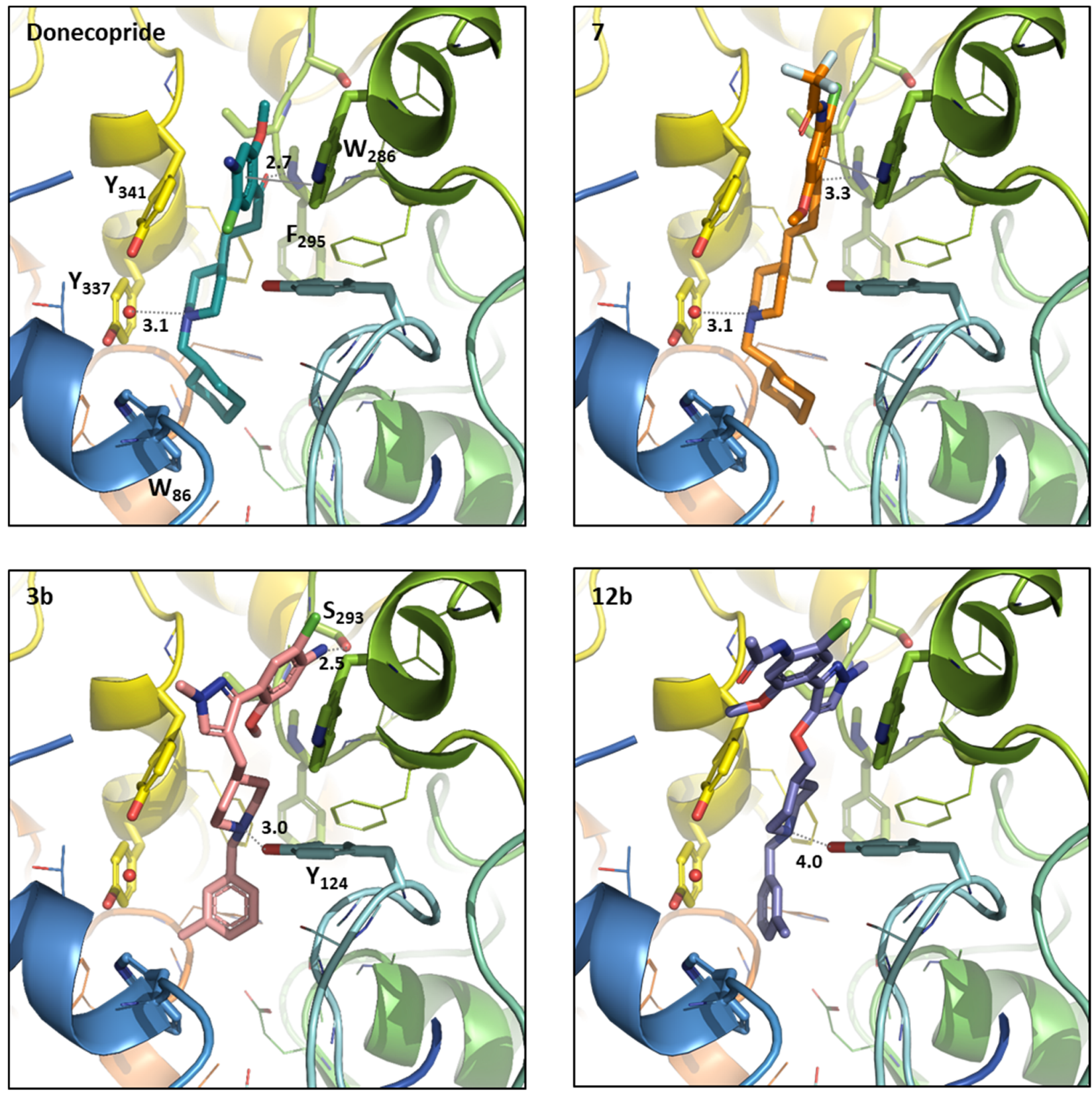

Figure 2. Donecopride (green) position compared to the compound $\mathbf{7}$ (orange), $\mathbf{3 b}$ (pink), and 12b (purple) positioned in $h \mathrm{AChE}$ binding sites using the docking studies. The compound and the selected side chains of the binding site residues are in stick and the protein in ribbon representation. This figure was made with PYMOL (DeLano Scientific, South San Francisco, CA, USA, 2002, San Carlo, Redwood City, CA, USA) and the protein is presented in the same orientation in all four images. 
However, the first docking does not produce conclusive results for compound $\mathbf{3 b}$. Compound $\mathbf{3} \mathbf{b}$ was systematically placed with aniline moiety at the bottom of the binding site cavity. Therefore, a second docking with a greater number of docking cycles was tested for compound $\mathbf{3 b}$. This docking generated even some more logical poses of compound $\mathbf{3 b}$ with aniline moiety placed at the binding cavity entrance. The generated solution with good orientation of aniline moiety corresponded to the score fit 91.78 is present in Figure 2.

The compound $\mathbf{3 b}$ docked in the $h \mathrm{AChE}$ active site higher compared to the donecopride in the same way as compound $\mathbf{1 2 b}$. Like $\mathbf{1 2 b}, \mathbf{3 b}$ compound lost the interaction through the piperidine's protonated nitrogen, $\pi$-stacking with $\operatorname{Trp}_{86}$, and the Hbond interaction due to carbonyl group absence in its scaffold (Figure 2). However, on the other hand with compound $\mathbf{1 2 b}, \mathbf{3 b}$ establishes new interactions through hydrogen bonds with the hydroxy group of $\mathrm{Tyr}_{124}$ and $\mathrm{Ser}_{293}$.

Based on this study we could state that the introduction of the methylpyrazole ring led to the loss of one of the crucial hydrogen bonds with the backbone $\mathrm{NH}$ of Phe 295 . In this series, the classical cation- $\pi$ interaction with $\mathrm{Tyr}_{337}$ is not enough to maintain the affinity of the cyclohexyl 3a. The replacement of the cyclohexyl by the aromatic $m$-tolyl led to clear impact on AChE inhibition surely by increasing the stacking of the aromatic ring of $\mathbf{3 b}$ with Phe 86 (Figure 2). Both interactions as well as hydrophobic interactions in the aromatic gorge could then justify the interesting properties of the novel phenyl pyrazole $\mathbf{3 b}$.

In order to better understand their worst profile on serotonergic receptors, docking studies were performed in a homology model of the $5-\mathrm{HT}_{4}$ and $5-\mathrm{HT}_{6}$ receptors. The docking results on $5-\mathrm{HT}_{4} \mathrm{R}$ for compounds $\mathbf{7}, \mathbf{3 b}$, and $\mathbf{1 2 b}$ were compared to donecopride one [6]. From donecopride docking, the selected pose was that where donecopride is placed horizontally in the cavity interacting on one side through an H-bond with Asp 100 on the transmembrane helix 3 (TM3, consistent with the constraint used during docking) and on other side through another H-bond with $\mathrm{Ser}_{197}$ on TM5 (in yellow in Figure 3). The donecopride's group assuring this second $\mathrm{H}$-bond is $\mathrm{NH}_{2}$ substituent on the benzene ring. Therefore, the addition of the substituent on $\mathrm{NH}_{2}$ group as well as the lengthening of the connector between the benzene cycle and the piperidine increase the compounds' length and the compounds can no longer be placed horizontally as donecopride. They take a curve position (Figure 3) and lost the interaction with TM5 in binding site. For compound 7, the position of its carbonyl group allowed it to maintain some electrostatic interactions with Ser 197 and $\mathrm{Asn}_{279}$, which is impossible for compound $\mathbf{1 2} \mathbf{b}$ and $\mathbf{3 b}$ through the replacement of this carbonyl group by the methylpyrazole ring. Hence, the hypothesis of their loss of affinity.

The comparison of the binding site of $5-\mathrm{HT}_{6} \mathrm{R}$ and $5-\mathrm{HT}_{4} \mathrm{R}$ showed that the various amino acids change and so modify the binding site topology. For example, in the 5- $\mathrm{HT}_{6} \mathrm{R}$, two tryptophan residues are in proximity of TM3 helix, $\operatorname{Trp}_{102}$ on TM3, and $\operatorname{Trp}_{92}$ in the ECL1 loop (Figure 4), and these two residues with a bulky lateral chains obstruct the space between the helices TM2 and TM3, which leads to the ligands no longer accessing this pocket, unlike the $5-\mathrm{HT}_{4} \mathrm{R}$. The binding cavity in $5-\mathrm{HT}_{6} \mathrm{R}$ is smaller than that of $5-\mathrm{HT}_{4} \mathrm{R}$ and therefore the ligands must take curved conformations to be able to access Asp $_{106}$. A supplementary interaction through $\pi$ stacking with Trp 102 was only observed for ligand $3 \mathbf{b}$ (Figure 4), which could explain the micromolar binding affinity of this ligand to $5-\mathrm{HT}_{6} \mathrm{R}$. 

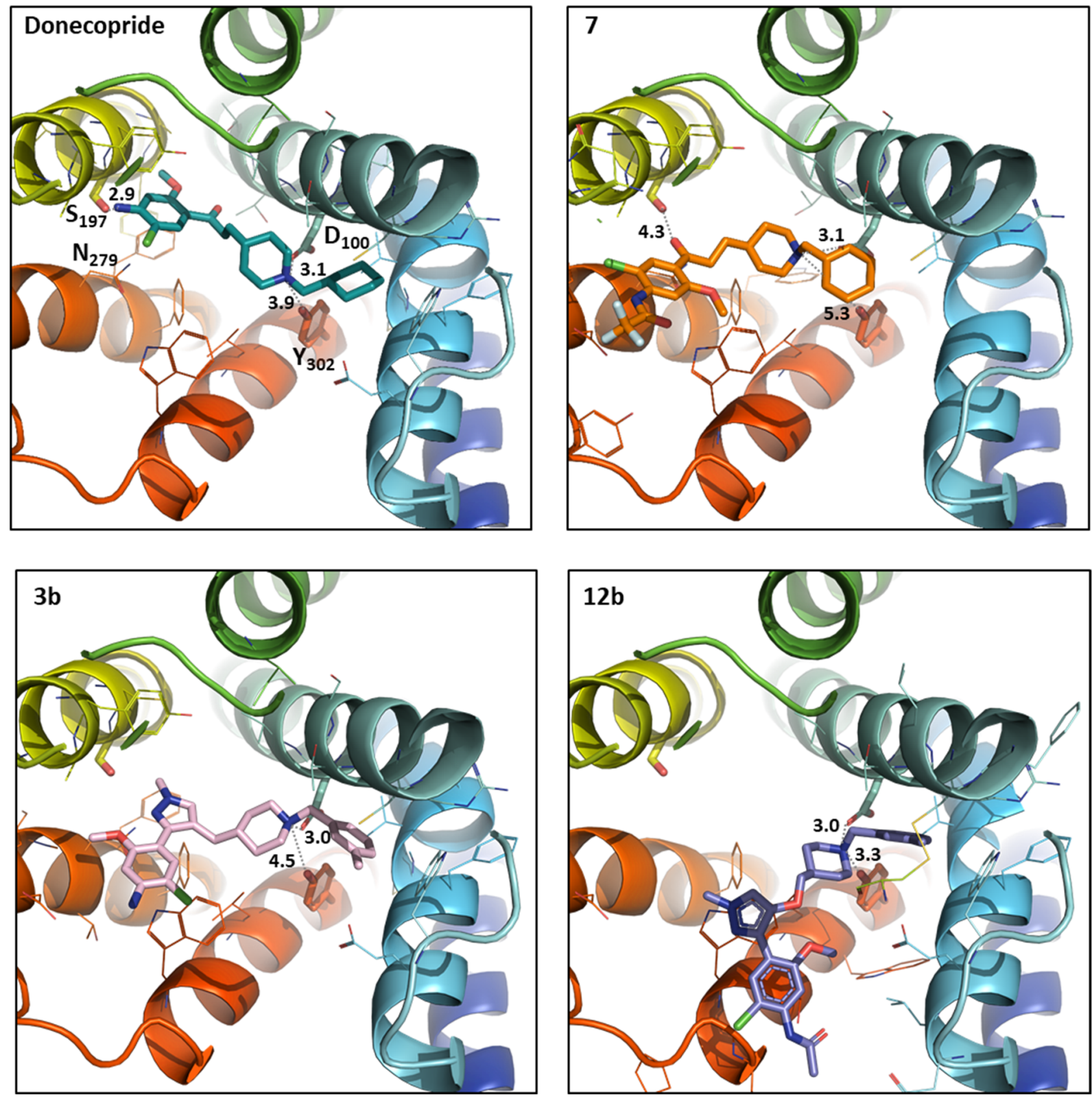

Figure 3. Donecopride (green) position compared to the compound $\mathbf{7}$ (orange), $\mathbf{3 b}$ (pink), and $\mathbf{1 2 b}$ (purple) positioned in $h 5-\mathrm{HT}_{4} \mathrm{R}$ binding sites using the docking studies. The compound and the selected side chains of the binding site residues are in stick and the protein in ribbon representation. This figure was made with PYMOL (DeLano Scientific, 2002, San Carlo, CA, USA) and the protein is presented in the same orientation in all four images. 

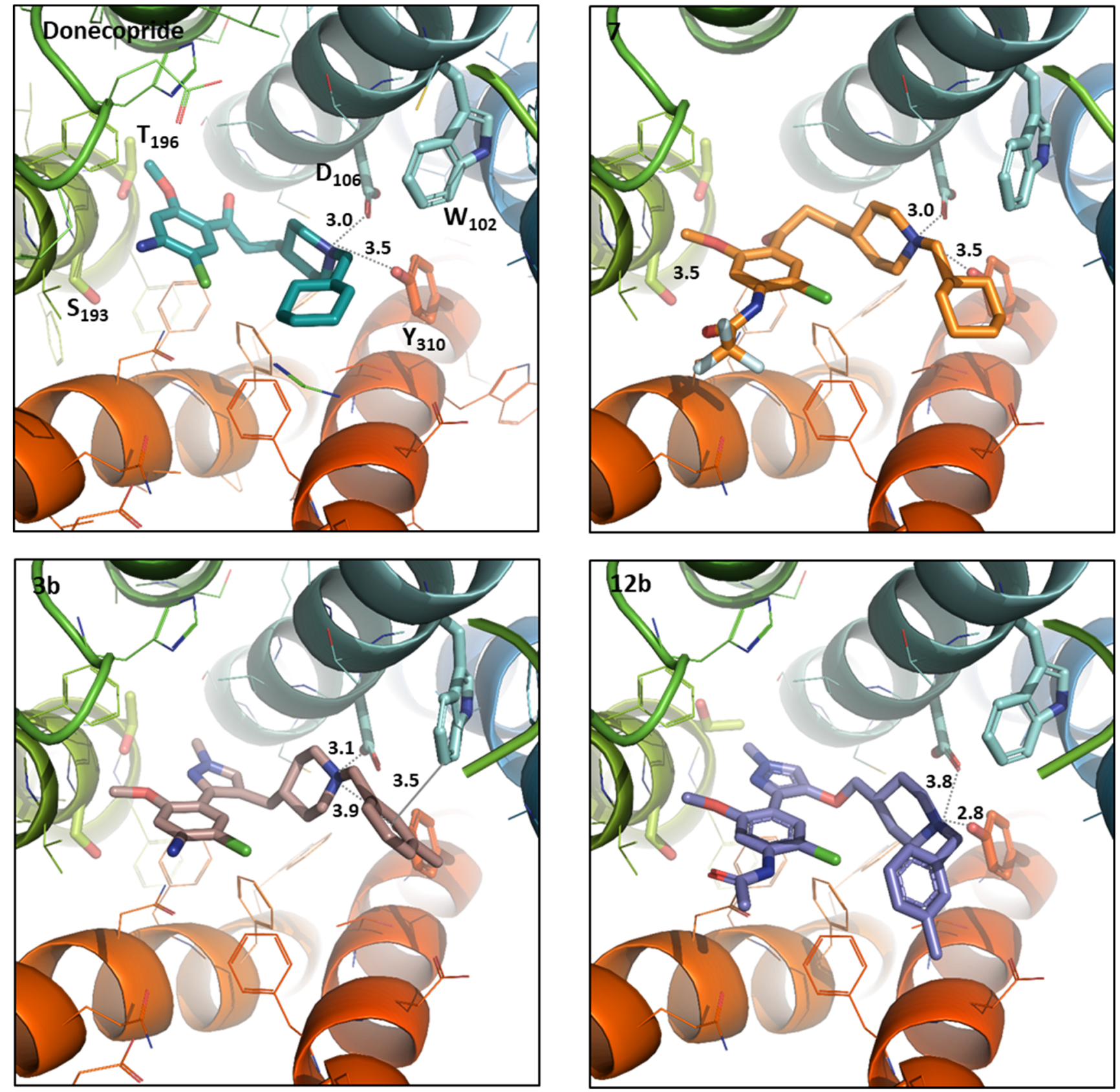

Figure 4. Donecopride (green) position compared to the compound $\mathbf{7}$ (orange), $\mathbf{3 b}$ (pink) and $\mathbf{1 2 b}$ (purple) positioned in $h-5 \mathrm{HT}_{6} \mathrm{R}$ binding sites using the docking studies. The compound and the selected side chains of the binding site residues are in stick and the protein in ribbon representation. This figure was made with PYMOL (DeLano Scientific, 2002, San Carlo, CA, USA) and the protein is presented in the same orientation in all four images.

\section{Experimental}

\subsection{Chemistry}

\subsubsection{General Methods}

All chemical reagents and solvents were purchased from commercial sources and used without further purification. Melting points were determined on a STUART SMP50 melting point apparatus (Cole-Parmer, Vernon Hills, IL, USA). ${ }^{1} \mathrm{H},{ }^{13} \mathrm{C}$, and ${ }^{19} \mathrm{~F}$ NMR spectra were recorded on a BRUKER AVANCE III $400 \mathrm{MHz}$ (Bruker, Billerica, MA, USA) apparatus with chemical shifts expressed in parts per million downfield from TMS as an internal standard and coupling in Hertz. IR spectra were recorded on a Perkin-Elmer BX FT-IR apparatus 
(Perkin Elmer, Wellesley, MA, USA) using KBr pellets. High-resolution mass spectra (HRMS) were obtained by electrospray on a BrukermaXis (Bruker, Billerica, MA, USA). The purities of all tested compounds were analyzed by LC-MS, with the purity all being higher than 95\%. Analyses were performed using a Waters Alliance 2695 (Waters corporation, Milford, MA, USA) as separating module (column XBridge C18 $2.5 \mu \mathrm{M} / 4.6 \times 50 \mathrm{mM}$ ) using the following gradients: A $(95 \%) / \mathrm{B}(5 \%)$ to $\mathrm{A}(5 \%) / \mathrm{B}(95 \%)$ in $4.00 \mathrm{~min}$. This ratio was hold during $1.50 \mathrm{~min}$ before return to initial conditions in $0.50 \mathrm{~min}$. Initial conditions were then maintained for $2.00 \min \left(\mathrm{A}=\mathrm{H}_{2} \mathrm{O}, \mathrm{B}=\mathrm{CH}_{3} \mathrm{CN}\right.$; each containing $\left.\mathrm{HCOOH}: 0.1 \%\right)$. MS were obtained on a SQ detector by positive ESI.

\subsubsection{Synthesis of Compounds (2-7, 9-12)}

tert-butyl 4-((3-(4-amino-5-chloro-2-methoxyphenyl)-1-methyl-1H-pyrazol-4-yl)methyl)piperidine1-carboxylate 2. An amount of $375 \mathrm{mg}$ of compound $1(0.947 \mathrm{mmol})$ were refluxed in $5 \mathrm{~mL}$ of DMF.DMA overnight. After evaporation under reduced pressure, the residue was dissolved in $10 \mathrm{~mL}$ of EtOH and $26 \mathrm{~mL}$ of methylhydrazine (3.788 mmol, $4 \mathrm{eq}$ ) were added. The mixture was refluxed for $4 \mathrm{~h}$. After concentration, the new residue was dissolved in $20 \mathrm{~mL}$ of $\mathrm{EtOH}$ and $645 \mathrm{mg}$ of $\mathrm{ZnCl}_{2}$ (4.735 mmol, $\left.5 \mathrm{eq}\right)$ were added. The new reactional mixture was refluxed for $2 \mathrm{~h}$ and then concentrated. The residue was dissolved in DCM and washed 3 times with water. The organic phase was dried on $\mathrm{MgSO}_{4}$, concentrated and purified on neutral $\mathrm{Al}_{2} \mathrm{O}_{3}$ to afford $155 \mathrm{mg}$ of product 2 as a brown solid. Yield $=38 \%$; m.p. $=67-69{ }^{\circ} \mathrm{C} ;{ }^{1} \mathrm{H}-\mathrm{NMR}\left(\mathrm{CDCl}_{3}, 400 \mathrm{MHz}\right): 7.17(\mathrm{~s}, 1 \mathrm{H}), 7.15(\mathrm{~s}, 1 \mathrm{H}), 6.34(\mathrm{~s}, 1 \mathrm{H}), 4.10$ (br s, 2H), 3.99 (br s, 2H), $3.87(\mathrm{~s}, 3 \mathrm{H}), 3.71(\mathrm{~s}, 3 \mathrm{H}), 2.57(\mathrm{t}, J=13.0 \mathrm{~Hz}, 2 \mathrm{H}), 2.29$ (d, J = 7.0 $\mathrm{Hz}, 2 \mathrm{H}), 1.54(\mathrm{~d}, J=13.1 \mathrm{~Hz}, 2 \mathrm{H}), 1.45-1.38(\mathrm{~m}, 10 \mathrm{H}), 0.97\left(\mathrm{qd}, J=12.2 \mathrm{~Hz}, J^{\prime}=4.2 \mathrm{~Hz}, 2 \mathrm{H}\right)$; ${ }^{13} \mathrm{C}-\mathrm{NMR}\left(\mathrm{CDCl}_{3}, 100 \mathrm{MHz}\right):$ 156.8, 154.9, 147.4, 143.5, 131.7, 129.3, 118.7, 114.4, 110.7, 98.7, 79.2, 55.6, $44.0(2 \mathrm{C}), 38.9,37.0,32.0(2 \mathrm{C}), 31.1,28.5(3 \mathrm{C}) ; \mathrm{MS}[\mathrm{M}+\mathrm{H}]^{+}=434.86$; IR (KBr, $\left.\mathrm{cm}^{-1}\right): 3468,3351,2931,1686,1624,1461,1444,1426,1365,1247,1211,1173,1211$.

\section{General Procedure for Acetylation}

The aniline was stirred in anhydric acetic $\left(6 \mathrm{~mL} \cdot \mathrm{mmol}^{-1}\right)$ at room temperature overnight. The mixture was concentrated under reduced pressure. The residue i was then dissolved in EtOAc and washed twice with aq. $\mathrm{NaHCO}_{3}$ saturated and once with water. The organic phase was dried, filtrated, and evaporated in vacuo. The crude product is purified on silica gel.

tert-butyl 4-(3-(4-acetamido-5-chloro-2-methoxyphenyl)-3-oxopropyl)piperidine-1-carboxylate 4. From $150 \mathrm{mg}$ of compound $1(0.379 \mathrm{mmol}), 129 \mathrm{mg}$ of compound 4 were obtained as a white solid (gradient of elution: DCM to DCM/EtOAc 9/1). Yield = 78\%; m.p. =123-125 ${ }^{\circ} \mathrm{C} ;{ }^{1} \mathrm{H}-\mathrm{NMR}\left(\mathrm{CDCl}_{3}, 400 \mathrm{MHz}\right): 8.26$ (s, 1H), 7.80 (br s, 1H), 7.77 (s, 1H), 4.07 (br s, 2H), $3.90(\mathrm{~s}, 3 \mathrm{H}), 2.94(\mathrm{~m}, 2 \mathrm{H}), 2.65(\mathrm{~m}, 2 \mathrm{H}), 2.26(\mathrm{~s}, 3 \mathrm{H}), 1.66-1.56(\mathrm{~m}, 4 \mathrm{H}), 1.43(\mathrm{~s}, 9 \mathrm{H}), 1.42(\mathrm{~m}$, 1H), $1.08(\mathrm{~m}, 2 \mathrm{H}) ;{ }^{13} \mathrm{C}-\mathrm{NMR}\left(\mathrm{CDCl}_{3}, 100 \mathrm{MHz}\right): 199.6,168.7,158.5,154.9,138.8,130.6,123.4$, $113.7,104.0,79.2,56.0,44.0$ (2C), 40.9, 35.7, 32.1 (2C), 30.9, 28.5 (3C), 25.2; MS [M + H] $]^{+}=$ 438.84; IR (KBr, cm $\left.{ }^{-1}\right)$ : 3323, 2975, 2930, 2853, 1690, 1674, 1599, 1578, 1513, 1451, 1402, 1242, 1163, 1017. HRMS [M + H + Na] $]^{+}$calcd for $\mathrm{C}_{22} \mathrm{H}_{31} \mathrm{ClN}_{2} \mathrm{NaO}_{5}, 461.1819$, exp 461.1813.

tert-butyl 4-((3-(4-acetamido-5-chloro-2-methoxyphenyl)-1-methyl-1H-pyrazol-4-yl)methyl) piperidine-1-carboxylate 5 . From $38 \mathrm{mg}$ of compound $2(0.088 \mathrm{mmol}), 35 \mathrm{mg}$ of compound 5 were obtained as a white solid (gradient of elution: DCM to DCM/EtOAc 6/4). Yield = 83\%; m.p. $=147-149^{\circ} \mathrm{C} ;{ }^{1} \mathrm{H}-\mathrm{NMR}\left(\mathrm{CDCl}_{3}, 400 \mathrm{MHz}\right): 8.20$ (s, 1H), $7.71(\mathrm{~s}, 1 \mathrm{H}), 7.32(\mathrm{~s}, 1 \mathrm{H}), 7.17$ (s, 1H), 3.98 (br s, 2H), $3.88(\mathrm{~s}, 3 \mathrm{H}), 3.81(\mathrm{~s}, 3 \mathrm{H}), 2.56(\mathrm{t}, J=12.8 \mathrm{~Hz}, 2 \mathrm{H}), 2.31(\mathrm{~d}, J=7.0 \mathrm{~Hz}$, $2 \mathrm{H}), 2.26(\mathrm{~s}, 3 \mathrm{H}), 1.53(\mathrm{~d}, J=13.2 \mathrm{~Hz}, 2 \mathrm{H}), 1.45-1.38(\mathrm{~m}, 10 \mathrm{H}), 0.96\left(\mathrm{qd}, J=12.2 \mathrm{~Hz}, J^{\prime}=4.3\right.$ $\mathrm{Hz}, 2 \mathrm{H}) ;{ }^{13} \mathrm{C}-\mathrm{NMR}\left(\mathrm{CDCl}_{3}, 100 \mathrm{MHz}\right): 168.4,155.7,154.8,154.4,144.7,134.4,127.4,119.3$, $113.8,104.4,86.0,79.5,75.7,55.9,43.5$ (2C), 36.1, 33.7, $28.6(2 \mathrm{C}), 28.5$ (3C), 25.1; MS [M + H] ${ }^{+}$ = 476.82; IR (KBr, cm $\left.{ }^{-1}\right):$ 3420, 2930, 1688, 1584, 1527, 1450, 1388, 1244, 1161.

5-(4-amino-5-chloro-2-methoxyphenyl)-2-methyl-2,4-dihydro-3H-pyrazol-3-one 9a. A total of $300 \mathrm{mg}$ of compound $8(1.107 \mathrm{mmol}), 54 \mu \mathrm{L}$ of methylhydrazine $(0.996 \mathrm{mmol}, 0.9 \mathrm{eq})$, and 
$3 \mathrm{~mL}$ of EtOH were stirred under microwaves irradiation at $160{ }^{\circ} \mathrm{C}$ for $45 \mathrm{~min}$. The solvent was eliminated under reduced pressure and the residue was purified on silica gel (gradient of elution: DCM to EtOAc) to afford $143 \mathrm{mg}$ of compound $9 \mathrm{a}$ as a white solid. Yield $=57 \%$; m.p. $=203-205^{\circ} \mathrm{C} ;{ }^{13} \mathrm{C}-\mathrm{NMR}\left(\mathrm{CDCl}_{3}, 400 \mathrm{MHz}\right): 7.81(\mathrm{~s}, 1 \mathrm{H}), 6.27(\mathrm{~s}, 1 \mathrm{H}), 4.31$ (br s, 2H), $3.78(\mathrm{~s}, 3 \mathrm{H}), 3.68(\mathrm{~s}, 2 \mathrm{H}), 3.36(\mathrm{~s}, 3 \mathrm{H}) ;{ }^{13} \mathrm{C}-\mathrm{NMR}\left(\mathrm{CDCl}_{3}, 100 \mathrm{MHz}\right): 172.5,157.5,152.4$, 145.6, 128.0, 111.7, 111.4, 98.0, 55.6, 42.1, 31.3; MS [M + H] $]^{+}=253.92 ; \mathrm{IR}\left(\mathrm{KBr}, \mathrm{cm}^{-1}\right)$ : 3448, $3331,2958,2229,1677,1631,1603,1572,1458,1348,1214,1049$; HRMS [M + H] ${ }^{+}$calcd for $\mathrm{C}_{11} \mathrm{H}_{13} \mathrm{ClN}_{3} \mathrm{O}_{2}, 254.0696, \exp 254.0693$.

3-(4-acetamido-5-chloro-2-methoxyphenyl)-1-methyl-1H-pyrazol-5-yl acetate 11. A total of $200 \mathrm{mg}$ of compound 9a $(0.80 \mathrm{mmol})$ were stirred in $2 \mathrm{~mL}$ of anhydric acetic at room temperature overnight. Water was added to obtain a white suspension. This latter was filtrated and washed with water. A total of $250 \mathrm{mg}$ of product 11 were then obtained as a white solid. Yield $=94 \%$. m.p. $=191-193^{\circ} \mathrm{C} ;{ }^{1} \mathrm{H}-\mathrm{NMR}\left(\mathrm{CDCl}_{3}, 400 \mathrm{MHz}\right): 8.21(\mathrm{~s}, 1 \mathrm{H}), 7.92(\mathrm{~s}, 1 \mathrm{H}), 7.68$ $(\mathrm{s}, 1 \mathrm{H}), 6.61(\mathrm{~s}, 1 \mathrm{H}), 3.89(\mathrm{~s}, 3 \mathrm{H}), 3.73(\mathrm{~s}, 3 \mathrm{H}), 2.35(\mathrm{~s}, 3 \mathrm{H}), 2.25(\mathrm{~s}, 3 \mathrm{H}),{ }^{13} \mathrm{C}-\mathrm{NMR}\left(\mathrm{CDCl}_{3}\right.$, $100 \mathrm{MHz})$ : 168.4, 166.1, 155.8, 145.1, 144.8, 134.6, 127.3, 118.8, 113.6, 104.3, 95.5, 55.9, 34.7, 25.1, 20.7; MS $[\mathrm{M}+\mathrm{H}]^{+}=337.92 ; \mathrm{IR}\left(\mathrm{KBr}, \mathrm{cm}^{-1}\right): 3422,2945,1787,1772,1699,1585,1511$, $1483,1450,1352,1243,1191,1011$. HRMS $[\mathrm{M}+\mathrm{H}]^{+}$calcd for $\mathrm{C}_{15} \mathrm{H}_{17} \mathrm{ClN}_{3} \mathrm{O}_{4}, 338.0908$, exp 338.0914 .

N-(2-chloro-5-methoxy-4-(1-methyl-5-oxo-4,5-dihydro-1H-pyrazol-3-yl)phenyl)acetamide 9b. A total of $250 \mathrm{mg}$ of compound $11(0.742 \mathrm{mmol})$ and $21 \mathrm{mg}$ of $\mathrm{LiOH}(0.890 \mathrm{mmol}, 1.2 \mathrm{eq})$ were dissolved in $14 \mathrm{~mL}$ of $\mathrm{EtOH} /$ water (5/2). The reactional mixture was stirred at room temperature for $1 \mathrm{~h} 45 \mathrm{~min}$. After evaporation in vacuo, water was added, adjusted at $\mathrm{pH}$ 4-5 and extracted 3 times with $\mathrm{CHCl}_{3}$. The organic phases were combined, washed once with water, dried on $\mathrm{MgSO}_{4}$, and concentrated to obtain $176 \mathrm{mg}$ of monoprotected compound $9 \mathrm{~b}$ and used without further purification. Yield $=76 \%$; m.p. $=219-221{ }^{\circ} \mathrm{C}$; ${ }^{1} \mathrm{H}-\mathrm{NMR}\left(\mathrm{CDCl}_{3}, 400 \mathrm{MHz}\right): 8.26$ (s, 1H), 7.94 (s, 1H), 7.73 (br s, 1H), 3.88 (s, 3H), 3.74 (s, 2H), 3.39 (s, 3H), 2.27 (s, 3H); ${ }^{13} \mathrm{C}-\mathrm{NMR}\left(\mathrm{CDCl}_{3}, 100 \mathrm{MHz}\right)$ 172.6, 168.6, 156.8, 151.6, $136.9,126.9,116.2,114.0,104.1,56.0,42.0,31.3,25.2 ; \mathrm{MS}[\mathrm{M}+\mathrm{H}]^{+}=295.85 ; \mathrm{IR}\left(\mathrm{KBr}, \mathrm{cm}^{-1}\right)$ : $3316,2340,1681,1606,1586,1547,1506,1450,1392,1209,1015$. HRMS [M + H] ${ }^{+}$calcd for $\mathrm{C}_{13} \mathrm{H}_{15} \mathrm{ClN}_{3} \mathrm{O}_{3}, 296.0802, \exp 296.0803$.

\section{General Procedure for the O-Alkylation}

The pyrazolone was dissolved in $\operatorname{DMF}\left(3 \mathrm{~mL} \cdot \mathrm{mmol}^{-1}\right)$ and $\mathrm{K}_{2} \mathrm{CO}_{3}(2 \mathrm{eq})$ and $N$-Boc4-iodomethylpiperidine (1.2 eq) were added. The mixture was stirred for $3 \mathrm{~h}$ at $60{ }^{\circ} \mathrm{C}$. After cooling, the brown solution was diluted in water and extracted 3 times with EtOAc. The organic phases were combined, washed 5 times with water, dried on $\mathrm{MgSO}_{4}$, and concentrated under reduced pressure. The crude product was then purified on silica gel (eluant DCM to DCM/EtOAc 8/2).

Tert-butyl 4-(((3-(4-acetamido-5-chloro-2-methoxyphenyl)-1-methyl-1H-pyrazol-5-yl)oxy)methyl) piperidine-1-carboxylate $\mathbf{1 0 b}$. From $167 \mathrm{mg}$ of compound $9 \mathrm{~b}(0.379 \mathrm{mmol}), 60 \mathrm{mg}$ of compound 10b were obtained as a white solid. Yield $=22 \%$; m.p. $=182-184{ }^{\circ} \mathrm{C} ;{ }^{1} \mathrm{H}-\mathrm{NMR}$ $\left(\mathrm{CDCl}_{3}, 400 \mathrm{MHz}\right): 8.19$ (s, 1H), 7.89 (s, 1H), 7.69 (br s, 1H), 6.00 (s, 1H), 4.15 (br s, 2H), 3.92 $(\mathrm{d}, J=6.3 \mathrm{~Hz}, 2 \mathrm{H}), 3.89(\mathrm{~s}, 3 \mathrm{H}), 3.66(\mathrm{~s}, 3 \mathrm{H}), 2.73(\mathrm{t}, J=13.0 \mathrm{~Hz}, 2 \mathrm{H}), 2.23(\mathrm{~s}, 3 \mathrm{H}), 1.98(\mathrm{~m}$, $1 \mathrm{H}), 1.78(\mathrm{~d}, J=12.6 \mathrm{~Hz}, 2 \mathrm{H}), 1.45(\mathrm{~s}, 9 \mathrm{H}), 1.27$ (qd, $\left.J=12.1 \mathrm{~Hz}, J^{\prime}=4.2 \mathrm{~Hz}, 2 \mathrm{H}\right){ }^{13} \mathrm{C}-\mathrm{NMR}$ $\left(\mathrm{CDCl}_{3}, 100 \mathrm{MHz}\right):$ 168.4, 155.7, 154.8, 154.4, 144.7, 134.4, 127.4, 119.3, 113.8, 104.4, 86.0, 79.5, $75.7,55.9,43.5(2 \mathrm{C}), 36.1,33.7,28.6(2 \mathrm{C}), 28.5(3 \mathrm{C}), 25.1 ;[\mathrm{M}+\mathrm{H}]^{+}=492.76 ; \mathrm{IR}\left(\mathrm{KBr}, \mathrm{cm}^{-1}\right)$ : 3420, 2936, 2853, 1690, 1585, 1557, 1528, 1450, 1436, 1365, 1247, 1173, 1147, 1018.

Tert-butyl 4-(((1-methyl-3-phenyl-1H-pyrazol-5yl)oxy)methyl)piperidine-1-carboxylate 10c. From $218 \mathrm{mg}$ of compound 9c $(0.647 \mathrm{mmol}), 129 \mathrm{mg}$ of compound 10c were obtained as a yellow solid. Yield $=27 \%$; m.p. $=133-135{ }^{\circ} \mathrm{C} ;{ }^{1} \mathrm{H}-\mathrm{NMR}\left(\mathrm{CDCl}_{3}, 400 \mathrm{MHz}\right): 7.73(\mathrm{~m}, 2 \mathrm{H}), 7.37(\mathrm{~m}$, 2H), $7.27(\mathrm{~m}, 1 \mathrm{H}), 5.80(\mathrm{~s}, 1 \mathrm{H}), 4.16(\mathrm{br} \mathrm{s}, 2 \mathrm{H}), 3.93(\mathrm{~d}, J=6.4 \mathrm{~Hz}, 2 \mathrm{H}), 3.68(\mathrm{~s}, 3 \mathrm{H}), 2.75(\mathrm{t}$, $J=12.8 \mathrm{~Hz}, 2 \mathrm{H}), 2.00(\mathrm{~m}, 1 \mathrm{H}), 1.80(\mathrm{~d}, J=13.0 \mathrm{~Hz}, 2 \mathrm{H}), 1.47(\mathrm{~s}, 9 \mathrm{H}), 1.29$ (qd, J=11.8 Hz, 
$\left.J^{\prime}=4.6 \mathrm{~Hz}, 2 \mathrm{H}\right) ;{ }^{13} \mathrm{C}-\mathrm{NMR}\left(\mathrm{CDCl}_{3}, 400 \mathrm{MHz}\right): 155.1,154.8,149.3,133.8,128.5$ (2C), 127.6, $125.2(2 \mathrm{C}), 82.0,79.6,75.9,43.5(2 \mathrm{C}), 36.0,33.8,28.6(2 \mathrm{C}), 28.5(3 \mathrm{C}) ; \mathrm{MS}[\mathrm{M}+\mathrm{H}]^{+}=372.01$; IR (KBr, cm $\left.{ }^{-1}\right)$ : 3426, 2925, 2853, 1742, 1690, 1626, 1558, 1512, 1454, 1422, 1367, 1275.

Tert-butyl 4-((3-(3,4-dimethoxyphenyl)-1-methyl-1H-pyrazol-5-yl)oxy)methyl)piperidine-1-carboxylate 10d. From $151 \mathrm{mg}$ of compound $\mathbf{9 d}(0.379 \mathrm{mmol}), 80 \mathrm{mg}$ of compound 10d were obtained as a yellow oil. Yield $=21 \%$; ${ }^{1} \mathrm{H}-\mathrm{NMR}\left(\mathrm{CDCl}_{3}, 400 \mathrm{MHz}\right): 7.33(\mathrm{~d}, J=2.0 \mathrm{~Hz}, 1 \mathrm{H}), 7.22(\mathrm{~d}, J=8.2$ $\left.\mathrm{Hz}, J^{\prime}=2.0 \mathrm{~Hz}, 1 \mathrm{H}\right), 6.86(\mathrm{~d}, J=8.3 \mathrm{~Hz}, 1 \mathrm{H}), 5.74(\mathrm{~s}, 1 \mathrm{H}), 4.18(\mathrm{br} \mathrm{s}, 2 \mathrm{H}), 3.95(\mathrm{~s}, 3 \mathrm{H}), 3.93$ $(\mathrm{d}, J=6.4 \mathrm{~Hz}, 2 \mathrm{H}), 3.90(\mathrm{~s}, 3 \mathrm{H}), 3.67(\mathrm{~s}, 3 \mathrm{H}), 2.75(\mathrm{t}, J=13.0 \mathrm{~Hz}, 2 \mathrm{H}), 2.00(\mathrm{~m}, 1 \mathrm{H}), 1.79(\mathrm{~d}$, $J=10.3 \mathrm{~Hz}, 2 \mathrm{H}), 1.47(\mathrm{~s}, 9 \mathrm{H}), 1.29(\mathrm{qd}, J=11.7 \mathrm{~Hz}, J=3.9 \mathrm{~Hz}, 2 \mathrm{H}) ; \mathrm{MS}[\mathrm{M}+\mathrm{H}]^{+}=431.91$;

General Procedure for the N-Alkylation

The protected compound $(0.167 \mathrm{mmol})$ was dissolved in DCM $\left(15 \mathrm{~mL} \cdot \mathrm{mmol}^{-1}\right)$ and TFA ( $\left.2 \mathrm{~mL} \cdot \mathrm{mmol}^{-1}\right)$ was added. The solution was stirred for $15 \mathrm{~min}$. After concentration, the residue was dissolved in acetone (for the benzylation) or DMF (for the alkylation) and $\mathrm{K}_{2} \mathrm{CO}_{3}$ (10 eq) and 3-methylbenzyl bromide (1.2 eq) or (bromomethyl)cyclohexane (1.3 eq) were added. The mixture was stirred at room temperature (for the benzylation) or warmed at $110{ }^{\circ} \mathrm{C}$ (for the alkylation) for $3 \mathrm{~h}$ and then concentrated under reduced pressure. The residue was dissolved in a mixture of $\mathrm{NaCl}$ sat/EtOAc. The organic phase was dried and evaporated. The crude was then purified on neutral $\mathrm{Al}_{2} \mathrm{O}_{3}$ (gradient of elution: DCM to $\mathrm{DCM} / \mathrm{EtOAc} 8 / 2$ ).

2-chloro-4-(4-((1-(cyclohexylmethyl)piperidin-4-yl)methyl)-1-methyl-1H-pyrazol-3-yl)-5-methoxyaniline 3a. From $59 \mathrm{mg}$ of compound $2(0.136 \mathrm{mmol}), 18 \mathrm{mg}$ of compound $3 \mathrm{a}$ were obtained as a pale brown gum. Yield $=31 \%$; ${ }^{1} \mathrm{H}-\mathrm{NMR}\left(\mathrm{CDCl}_{3}, 400 \mathrm{MHz}\right): 7.17(\mathrm{~s}, 1 \mathrm{H}), 7.15(\mathrm{~s}, 1 \mathrm{H}), 6.34(\mathrm{~s}, 1 \mathrm{H}), 4.09$ (br s, 2H), $3.88(\mathrm{br} \mathrm{s}, 2 \mathrm{H}), 3.72(\mathrm{~s}, 3 \mathrm{H}), 2.83(\mathrm{~m}, 2 \mathrm{H}), 2.29(\mathrm{~d}, J=6.6 \mathrm{~Hz}, 2 \mathrm{H}), 2.10(\mathrm{~m}, 2 \mathrm{H})$, $1.78-1.10(\mathrm{~m}, 17 \mathrm{H}), 0.89-0.80(\mathrm{~m}, 2 \mathrm{H}) ;{ }^{13} \mathrm{C}-\mathrm{NMR}\left(\mathrm{CDCl}_{3}, 100 \mathrm{MHz}\right): 156.8,147.4,143.4$, $131.8,129.4,119.1,114.6,110.7,98.7,66.0,55.6,54.4$ (2C), 38.9, 36.9, 35.1, $32.0(2 \mathrm{C}), 31.9$ (2C), 31.1, 26.7, $26.1(2 \mathrm{C})$; MS [M + H] $]^{+}=431.02 ; \mathrm{IR}\left(\mathrm{KBr}, \mathrm{cm}^{-1}\right): 3438,2921,2849,1622,1525$, $1461,1445,1402,1211$. HRMS [M + H] ${ }^{+}$calcd for $\mathrm{C}_{24} \mathrm{H}_{36} \mathrm{ClN}_{4} \mathrm{O}, 431.2578$, $\exp 431.2576$.

2-chloro-5-methoxy-4-(1-methyl-4-((1-(3-methylbenzyl)piperidin-4-yl)methyl)-1H-pyrazol3-yl)aniline $\mathbf{3 b}$. From $41 \mathrm{mg}$ of compound $2(0.095 \mathrm{mmol}), 19 \mathrm{mg}$ of compound $\mathbf{3 b}$ were obtained as a pale yellow gum. Yield $=46 \% ;{ }^{1} \mathrm{H}-\mathrm{NMR}\left(\mathrm{CDCl}_{3}, 400 \mathrm{MHz}\right): 7.18(\mathrm{t}, J=7.6$ $\mathrm{Hz}, 1 \mathrm{H}), 7.17(\mathrm{~s}, 1 \mathrm{H}), 7.14(\mathrm{~s}, 1 \mathrm{H}), 7.10(\mathrm{~s}, 1 \mathrm{H}), 7.05(\mathrm{~m}, 2 \mathrm{H}), 6.33(\mathrm{~s}, 1 \mathrm{H}), 4.09$ (br s, 2H), 3.86 $(\mathrm{s}, 3 \mathrm{H}), 3.71(\mathrm{~s}, 3 \mathrm{H}), 3.40(\mathrm{~s}, 2 \mathrm{H}), 2.81(\mathrm{~m}, 2 \mathrm{H}), 2.33(\mathrm{~s}, 3 \mathrm{H}), 2.28(\mathrm{~d}, J=6.8 \mathrm{~Hz}, 2 \mathrm{H}), 1.82(\mathrm{td}$, $\left.J=11.8 \mathrm{~Hz}, J^{\prime}=2.4 \mathrm{~Hz}, 2 \mathrm{H}\right), 1.55(\mathrm{~d}, J=12.7 \mathrm{~Hz}, 2 \mathrm{H}), 1.28(\mathrm{~m}, 1 \mathrm{H}), 1.15(\mathrm{qd}, J=12.3 \mathrm{~Hz}$, $\left.J^{\prime}=3.6 \mathrm{~Hz}, 2 \mathrm{H}\right) .{ }^{13} \mathrm{C}-\mathrm{NMR}\left(\mathrm{CDCl}_{3}, 100 \mathrm{MHz}\right): 156.8,147.4,143.4,138.4,137.7,131.8,130.0$, 129.3, 128.0, 127.6, 126.4, 119.2, 114.6, 110.7, 98.7, 63.6, 55.6, 53.9 (2C), 38.9, 36.9, 32.2 (2C), 31.1, 21.4; MS $[\mathrm{M}+\mathrm{H}]^{+}=439.74 ; \mathrm{IR}\left(\mathrm{KBr}, \mathrm{cm}^{-1}\right): 3434,2925,1623,1525,1460,1445,1402$, 1211. HRMS $[\mathrm{M}+\mathrm{H}]^{+}$calcd for $\mathrm{C}_{25} \mathrm{H}_{32} \mathrm{ClN}_{4} \mathrm{O}, 439.2265$, exp 439.2268.

N-(2-chloro-4-(4-((1-(cyclohexylmethyl)piperidin-4-yl)methyl)-1-methyl-1H-pyrazol-3-yl)5 -methoxyphenyl)acetamide 6 . From $60 \mathrm{mg}$ of compound 5 ( $0.126 \mathrm{mmol}), 32 \mathrm{mg}$ of compound 6 were obtained as a beige solid. Yield $=46 \%$; m.p. $=148-150{ }^{\circ} \mathrm{C} ;{ }^{1} \mathrm{H}-\mathrm{NMR}\left(\mathrm{CDCl}_{3}\right.$, $400 \mathrm{MHz}): 8.20(\mathrm{~s}, 1 \mathrm{H}), 7.70(\mathrm{br} \mathrm{s}, 1 \mathrm{H}), 7.31(\mathrm{~s}, 1 \mathrm{H}), 7.16(\mathrm{~s}, 1 \mathrm{H}), 3.87(\mathrm{~s}, 3 \mathrm{H}), 3.80(\mathrm{~s}, 3 \mathrm{H})$, $2.77(\mathrm{~d}, J=11.8 \mathrm{~Hz}, 2 \mathrm{H}), 2.29(\mathrm{~d}, J=6.8 \mathrm{~Hz}, 2 \mathrm{H}), 2.26(\mathrm{~s}, 3 \mathrm{H}), 2.03(\mathrm{~d}, J=7.0 \mathrm{~Hz}, 2 \mathrm{H})$, $1.74-1.61(\mathrm{~m}, 6 \mathrm{H}), 1.52(\mathrm{~d}, J=12.6 \mathrm{~Hz}, 2 \mathrm{H}), 1.43(\mathrm{~m}, 1 \mathrm{H}), 1.28-1.08(\mathrm{~m}, 7 \mathrm{H}), 0.87-0.77(\mathrm{~m}$, $2 \mathrm{H}) ;{ }^{13} \mathrm{C}-\mathrm{NMR}\left(\mathrm{CDCl}_{3}, 100 \mathrm{MHz}\right): 168.5,156.4,146.8,135.1,130.9,129.6,119.8,119.4,112.9$, $103.8,66.2,55.8,54.5$ (2C), 38.9, 37.0, 35.3, 32.3 (2C), 32.1 (2C), 31.2, 26.8, 26.2 (2C), 25.2; MS $[\mathrm{M}+\mathrm{H}]^{+}=472.92 ; \mathrm{IR}\left(\mathrm{KBr}, \mathrm{cm}^{-1}\right): 3420,2921,2849,1694,1625,1584,1527,1449,1388,1243$; HRMS [M + H] ${ }^{+}$calcd for $\mathrm{C}_{26} \mathrm{H}_{34} \mathrm{~N}_{3} \mathrm{O}_{3}, 473.2683$, $\exp 473.2682$.

N-(2-chloro-4-(3-(1-(cyclohexylmethyl)piperidin-4-yl)propanoyl)-5-methoxyphenyl)acetamide 7. From $81 \mathrm{mg}$ of compound $4(0.185 \mathrm{mmol}), 34 \mathrm{mg}$ of compound 7 were obtained as a beige gum. Yield $=42 \%$; ${ }^{1} \mathrm{H}-\mathrm{NMR}\left(\mathrm{CDCl}_{3}, 400 \mathrm{MHz}\right): 8.26(\mathrm{~s}, 1 \mathrm{H}), 7.77(\mathrm{~s}, 1 \mathrm{H}), 7.75(\mathrm{br} \mathrm{s}, 1 \mathrm{H}), 3.90$ $(\mathrm{s}, 3 \mathrm{H}), 2.93(\mathrm{t}, J=7.6 \mathrm{~Hz}, 2 \mathrm{H}), 2.83(\mathrm{~d}, J=11.0 \mathrm{~Hz}, 2 \mathrm{H}), 2.25(\mathrm{~s}, 3 \mathrm{H}), 2.05(\mathrm{~d}, J=7.1 \mathrm{~Hz}, 2 \mathrm{H})$, 
1.79-1.45 (m, 10H), 1.23-1.05 (m, 8H), 0.83 (m, 2H); ${ }^{13} \mathrm{C}-\mathrm{NMR}\left(\mathrm{CDCl}_{3}, 100 \mathrm{MHz}\right): 200.1$, 168.6, 158.4, 138.6, 130.6, 123.5, 113.5, 103.9, 66.2, 55.9, 53.3 (2C), 41.2, 35.7, 35.2, 32.2 (2C), 32.1 (2C), 31.0, 26.8, 26.2 (2C), 25.2; MS [M + H] ${ }^{+}=434.82 ; \mathrm{IR}\left(\mathrm{KBr}, \mathrm{cm}^{-1}\right): 3345,2921,2849$, $1704,1672,1599,1578,1512,1450,1401,1263,1241,1176,1014 ;$ HRMS [M + H] ${ }^{+}$calcd for $\mathrm{C}_{24} \mathrm{H}_{36} \mathrm{ClN}_{2} \mathrm{O}_{3}, 435.2414, \exp 435.2415$.

N-(2-chloro-5-methoxy-4-(1-methyl-5-((1-(3-methylbenzyl)piperidin-4-yl)methoxy)-1H-pyrazol3-yl)phenyl)acetamide 12b. From $70 \mathrm{mg}$ of compound $10 \mathrm{~b}(0.126 \mathrm{mmol}), 45 \mathrm{mg}$ of compound 12b were obtained as a beige solid. Yield $=64 \%$; m.p. $=174-176{ }^{\circ} \mathrm{C} ;{ }^{1} \mathrm{H}-\mathrm{NMR}\left(\mathrm{CDCl}_{3}, 400\right.$ MHz): 8.22 (s, 1H), 7.90 (s, 1H), 7.67 (br s, 1H), 7.21 (t, J = 7.4 Hz, 1H), 7.14-7.06 (m, 3H), 6.00 $(\mathrm{s}, 1 \mathrm{H}), 3.93(\mathrm{~d}, J=6.3 \mathrm{~Hz}, 2 \mathrm{H}), 3.91(\mathrm{~s}, 3 \mathrm{H}), 3.67(\mathrm{~s}, 3 \mathrm{H}), 3.48(\mathrm{~s}, 2 \mathrm{H}), 2.94(\mathrm{~d}, J=11.2 \mathrm{~Hz}$, 2H), $2.35(\mathrm{~s}, 3 \mathrm{H}), 2.25(\mathrm{~s}, 3 \mathrm{H}), 2.00\left(\mathrm{td}, J=11.9 \mathrm{~Hz}, J^{\prime}=2.5 \mathrm{~Hz}, 2 \mathrm{H}\right), 1.85-1.77(\mathrm{~m} 3 \mathrm{H}), 1.44$ $\left(\mathrm{qd}, J=11.9 \mathrm{~Hz}, J^{\prime}=3.7 \mathrm{~Hz}, 2 \mathrm{H}\right) ;{ }^{13} \mathrm{C}-\mathrm{NMR}\left(\mathrm{CDCl}_{3}, 100 \mathrm{MHz}\right): 168.4,155.7,154.7,144.7$, $138.2,137.8,134.4,130.0,128.1,127.8,127.4,126.3,119.4,113.7,104.3,86.0,76.2,63.5,56.0$, 53.3 (2C), 35.8, 33.7, 28.9 (2C), 25.1, 21.4; MS [M + H] ${ }^{+}=496.82 ; \mathrm{IR}\left(\mathrm{KBr}, \mathrm{cm}^{-1}\right): 3415,2937$, 1694, 1680, 1585, 1557, 1527, 1449, 1361, 1243; HRMS $[\mathrm{M}+\mathrm{H}]^{+}$calcd for $\mathrm{C}_{27} \mathrm{H}_{34} \mathrm{ClN}_{4} \mathrm{O}_{3}$, 497.2319, $\exp 497.2319$.

4-(((1-methyl-3-phenyl-1H-pyrazol-5-yl)oxy)methyl)-1-(3-methylbenzyl)piperidine 12c. From $62 \mathrm{mg}$ of compound 10c $(0.126 \mathrm{mmol}), 20 \mathrm{mg}$ of compound 12c were obtained as an oil. Yield $=32 \%$; ${ }^{1} \mathrm{H}-\mathrm{NMR}\left(\mathrm{CDCl}_{3}, 400 \mathrm{MHz}\right): 7.73(\mathrm{~m}, 2 \mathrm{H}), 7.37(\mathrm{~m}, 2 \mathrm{H}), 7.27(\mathrm{~m}, 1 \mathrm{H}), 7.22$ $(\mathrm{t}, J=7.5 \mathrm{~Hz}, 1 \mathrm{H}), 7.15(\mathrm{~s}, 1 \mathrm{H}), 7.13(\mathrm{~d}, J=7.5 \mathrm{~Hz}, 1 \mathrm{H}), 7.08(\mathrm{~d}, J=7.5 \mathrm{~Hz}, 1 \mathrm{H}), 5.80(\mathrm{~s}, 1 \mathrm{H})$, $3.94(\mathrm{~d}, J=6.4 \mathrm{~Hz}, 2 \mathrm{H}), 3.68(\mathrm{~s}, 3 \mathrm{H}), 3.52(\mathrm{~s}, 2 \mathrm{H}), 2.98(\mathrm{~d}, J=10.7 \mathrm{~Hz}, 2 \mathrm{H}), 2.35(\mathrm{~s}, 3 \mathrm{H}), 2.04$ $(\mathrm{t}, J=1.6 \mathrm{HZ}, 2 \mathrm{H}), 1.86(\mathrm{~m}, 1 \mathrm{H}), 1.80(\mathrm{~d}, J=13.5 \mathrm{~Hz}, 2 \mathrm{H}), 1.48(\mathrm{~m}, 2 \mathrm{H}) ;{ }^{13} \mathrm{C}-\mathrm{NMR}\left(\mathrm{CDCl}_{3}\right.$, $100 \mathrm{MHz})$ : 155.3, 149.3, 137.9, 137.6, 133.9, 130.1, 128.5 (2C), 128.1, 127.9, 127.5, 126.5, 125.2 (2C), 82.0, 76.2, 63.4, 53.2 (2C), 35.7, 33.8, 28.7 (2C), 21.4; MS [M + H] $]^{+}=376.00 ; \mathrm{HRMS}$ $[\mathrm{M}+\mathrm{H}]^{+}$calcd for $\mathrm{C}_{24} \mathrm{H}_{30} \mathrm{~N}_{3} \mathrm{O}, 376.2389$, exp 376.2392.

4-(((3-(3,4-dimethoxyphenyl)-1_methyl-1H-pyrazol-5-yl)oxy)methyl)-1-(3-methylbenzyl)piperidine 12d. From $70 \mathrm{mg}$ of compound $10 \mathrm{~d}(0.126 \mathrm{mmol}), 35 \mathrm{mg}$ of compound $\mathbf{1 2 d}$ were obtained as a pale brown oil. Yield $=67 \%$; ${ }^{1} \mathrm{H}-\mathrm{NMR}\left(\mathrm{CDCl}_{3}, 400 \mathrm{MHz}\right): 7.33(\mathrm{~d}, J=2.0 \mathrm{~Hz}, 1 \mathrm{H})$, $7.24-7.19(\mathrm{~m}, 2 \mathrm{H}), 7.14-7.06(\mathrm{~m}, 3 \mathrm{H}), 6.87(\mathrm{~d}, J=8.4 \mathrm{~Hz}, 1 \mathrm{H}), 5.73(\mathrm{~s}, 1 \mathrm{H}), 3.95(\mathrm{~s}, 3 \mathrm{H}), 3.93$ $(\mathrm{d}, J=6.4 \mathrm{~Hz}, 2 \mathrm{H}), 3.90(\mathrm{~s}, 3 \mathrm{H}), 3.67(\mathrm{~s}, 3 \mathrm{H}), 3.49(\mathrm{~s}, 2 \mathrm{H}), 2.95(\mathrm{~d}, J=11.7 \mathrm{~Hz}, 2 \mathrm{H}), 2.35$ (s, $3 \mathrm{H}), 2.00\left(\mathrm{td}, J=11.7 \mathrm{~Hz}, J^{\prime}=2.4 \mathrm{~Hz}, 2 \mathrm{H}\right), 1.85(\mathrm{~m}, 1 \mathrm{H}), 1.81(\mathrm{~d}, J=13.0 \mathrm{~Hz}, 2 \mathrm{H}), 1.44(\mathrm{qd}$, $J=12.3 \mathrm{~Hz}, J=3.7 \mathrm{~Hz}, 2 \mathrm{H}) ;{ }^{13} \mathrm{C}-\mathrm{NMR}\left(\mathrm{CDCl}_{3}, 100 \mathrm{MHz}\right): 155.3,149.2,149.0,148.7,138.1$, $137.8,130.0,128.1,127.8,127.1,126.4,117.8,111.0,108.1,81.7,76.3,63.5,55.9,55.9,53.2(2 \mathrm{C})$, 35.8, 33.7, 28.8 (2C), 21.4; MS [M + H] ${ }^{+}=435.94$; IR $\left(\mathrm{KBr}, \mathrm{cm}^{-1}\right): 2935,1609,1589,1558$, $1525,1466,1435,1258,1234,1029$; HRMS $[\mathrm{M}+\mathrm{H}]^{+}$calcd for $\mathrm{C}_{26} \mathrm{H}_{34} \mathrm{~N}_{3} \mathrm{O}_{3}, 436.2600$, exp 436.2596 .

\subsection{Biological Evaluation}

\subsubsection{In Vitro Tests of AChE Biological Activity}

Inhibitory capacity of compounds on AChE biological activity was evaluated through the use of the spectrometric method of Ellman [24]. Acetylthiocholine iodide and 5,5dithiobis-(2-nitrobenzoic) acid (DTNB) were purchased from Sigma Aldrich. AChE from human erythrocytes (buffered aqueous solution, $\geq 500$ units/mg protein (BCA), Sigma Aldrich) was diluted in $20 \mathrm{mM}$ HEPES buffer $\mathrm{pH} 8,0.1 \%$ Triton X-100 such as to have enzyme solution with $0.25 \mathrm{unit} / \mathrm{mL}$ enzyme activity. In the procedure, $100 \mu \mathrm{L}$ of $0.3 \mathrm{mM}$ DTNB dissolved in phosphate buffer $\mathrm{pH} 7.4$ were added into the 96 wells plate followed by $50 \mu \mathrm{L}$ of test compound solution and $50 \mu \mathrm{L}$ of enzyme $(0.05 \mathrm{U}$ final). After 5 min of preincubation at $25^{\circ} \mathrm{C}$, the reaction was then initiated by the injection of $50 \mu \mathrm{L}$ of $1 \mathrm{mM}$ acetylthiocholine iodide solution. The hydrolysis of acetylthiocholine was monitored by the formation of yellow 5-thio-2-nitrobenzoate anion as the result of the reaction of DTNB with thiocholine, released by the enzymatic hydrolysis of acetylthiocholine, at a wavelength of 412 nm using a 96-well microplate plate reader (Synergy 2, Biotek, Colmar, France). Test compounds were dissolved in analytical grade DMSO. Donepezil was used as a reference 
standard. The rate of absorbance increase at $412 \mathrm{~nm}$ was followed every minute for $10 \mathrm{~min}$. Assays were performed with a blank containing all components except acetylthiocholine, in order to account for non-enzymatic reaction. The reaction slopes were compared and the percent inhibition due to the presence of test compounds was calculated by the following expression: $100-(\mathrm{vi} / \mathrm{v} 0 \times 100)$ where vi is the rate calculated in the presence of inhibitor and $\mathrm{v} 0$ is the enzyme activity.

First screening of AChE activity was carried out at a $10^{-6} \mathrm{M}$ concentration of compounds under study. For the compounds with significant inhibition $(\geq 50 \%), \mathrm{IC}_{50}$ values were determined graphically by plotting the \% inhibition versus the logarithm of six inhibitor concentrations in the assay solution using the GraphPad Prism 6 software.

\subsubsection{Pharmacological Characterization of Drugs on Human $5-\mathrm{HT}_{4} \mathrm{R}$}

For competition studies, $2.5 \mu \mathrm{g}$ of proteins $\left(5-\mathrm{HT}_{4(\mathrm{~b})}\right.$ membrane preparations, $\mathrm{HTS} 110 \mathrm{M}$, Eurofins. Eurofins' $5-\mathrm{HT}_{4(\mathrm{~b})}$ membrane preparations are crude membrane preparations made from their proprietary stable recombinant cell lines to ensure high-level of GPCR surface expression.) were incubated in duplicate at $25^{\circ} \mathrm{C}$ for $60 \mathrm{~min}$ in the absence or the presence of $10^{-6}$ or $10^{-8} \mathrm{M}$ of each drug (RS67333 was used as a reference standard) and $0.5 \mathrm{nM}\left[{ }^{3} \mathrm{H}\right.$ ]-GR113808 (NET 1152, Perkin Elmer) in $25 \mathrm{mM}$ Tris buffer (pH 7.4, $25^{\circ} \mathrm{C}$ ). At the end of the incubation, homogenates were filtered through Whatman GF/C filters (Alpha Biotech) presoaked with $0.5 \%$ polyethylenimine using a Brandel cell harvester. Filters were subsequently washed three times with $1 \mathrm{~mL}$ of ice-cold $25 \mathrm{mM}$ Tris buffer $\left(\mathrm{pH} 7.4,4^{\circ} \mathrm{C}\right)$. Non-specific binding was evaluated in parallel in the presence of $30 \mu \mathrm{M}$ serotonin.

\subsubsection{Pharmacological Characterization of Drugs on Human $5-\mathrm{HT}_{6} \mathrm{R}$}

Drugs were evaluated through their possibility to compete for the binding of $\left[{ }^{3} \mathrm{H}\right]-\mathrm{LSD}$ on membranes of HEK-293 cells transiently expressing the human $5-\mathrm{HT}_{6}$ receptors (ref. RBHS6M, Perkin Elmer). In brief, $4 \mu \mathrm{g}$ of proteins were incubated at $37^{\circ} \mathrm{C}$ for $60 \mathrm{~min}$ in duplicate in the absence or the presence of $10^{-6}$ or $10^{-8} \mathrm{M}$ of each drug (serotonin was used as a reference standard) and $\left.2.5 \mathrm{nM} \mathrm{[}{ }^{3} \mathrm{H}\right]-\mathrm{LSD}$ (ref. NET638250UC, Perkin Elmer), in $25 \mathrm{mM}$ Tris- $\mathrm{HCl}$ buffer ( $\mathrm{pH} 7.4$ ) supplemented with $0.5 \mathrm{mM}$ EDTA. At the end of the incubation, the homogenates were then filtered through Whatman GF/C filters and washed five times with ice-cold $25 \mathrm{mM}$ Tris- $\mathrm{HCl}$ buffer. Non-specific binding was evaluated in the presence of $100 \mu \mathrm{M}$ serotonin. Radioactivity associated to proteins was then quantified and expressed as the percentage of inhibition of the drugs under study.

For some of these compounds, affinity constants were calculated from five-point inhibition curves using the GraphPad Prism 6 software and expressed as $\mathrm{Ki} \pm \mathrm{SD}$.

\subsection{In Silico Study}

The X-ray structure of donecopride was used as a 3D model during the docking and four conformers present in the crystal cell were used. The initial model of compounds 7 , $3 \mathbf{b}$, and $\mathbf{1 2} \mathbf{b}$ were built from donecopride $X$-ray structure [6]. The compound's protonation state at $\mathrm{pH} 7.4$ was predicted using standard tools of the ChemAxon Package (http:/ / www. chemaxon.com/, accessed on 23 February 2021). The majority microspecie protonated on piperidine nitrogen at this $\mathrm{pH}$ was used for docking studies of each compounds.

The crystallographic coordinates of human acetylcholinesterase used in this study were obtained from X-ray structure of the donepezil/AChE complex (PDB ID 4EY7, a structure refined to $2.35 \AA$ with an $\mathrm{R}$ factor of $17.7 \%$ ) [25]. The AChE amino acid protonation state was checked before the docking study using the ProPKA software and the proposed protonation for Glu202 was applied.

The docking of the donepezil, donecopride, and compounds $3 \mathbf{b}, \mathbf{7}$, and $\mathbf{1 2 b}$ into the AChE was carried out with the GOLD program (v2020.2.0) using the default parameters [26,27]. This program applies a genetic algorithm to explore conformational spaces and ligand binding modes. To evaluate the proposed ligand positions, the ChemPLP fitness 
function was used. The binding site in the AChE model was defined as a $7 \AA$ sphere from the co-crystallized donepezil ligand and a water molecule interacting with protonated piperidine ring of donepezil was conserved during the docking (residue number 931). The second docking with the higher number of docking cycles (20 cycles) was carried out for compound $\mathbf{3 b}$.

For the docking studies into $5-\mathrm{HT}_{4}$ receptor, the $3 \mathrm{D}$ model of the human $5-\mathrm{HT}_{4} \mathrm{R}$ built previously by homology sequence approach [28] was used. This model was generated using the crystal structure (PBD: 2RH1) of the human $\beta_{2}$ adrenergic receptor-T4 lysozyme fusion protein complexed with the carazolol [29] as a template. The docking of the donecopride and $\mathbf{7}, \mathbf{3 b}, \mathbf{1 2} \mathbf{b}$ compounds into the generated model was carried out with the GOLD program (v2020.2.0) using the default parameters [26,27] and the proposed ligand positions were evaluated by the ChemPLP fitness function. The binding site in the $5-\mathrm{HT}_{4} \mathrm{R}$ model was

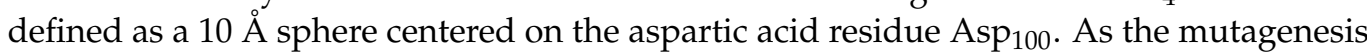
studies have shown that the interaction between the positively ionizable amine of ligands and Asp100 of 5- $\mathrm{HT}_{4} \mathrm{R}$ is crucial for ligand binding, a hydrogen bond constraint between positively ionizable amine ligand and OD atom of $\mathrm{Asp}_{100}$ was used during the docking [30] Furthermore, special attention was paid during the docking procedure to the following amino acids in the binding site, which were kept flexible: Arg96, Asp100, Thr104, Tyr192, Ser197, and Trp294.

For the docking studies on the $5-\mathrm{HT}_{6}$ receptor first a homology model was built. The sequence of the human $5-\mathrm{HT}_{6} \mathrm{R}$ was retrieved from the UniProt Knowledgebase (UniProtKB) [31] (ID: P50406_HUMAN). Using screening methods like FUGUE [32], SP3 [33], PSIBLAST, [34,35] HHSEARCH [36], and the @tome-2 server [37], the $\beta_{2}$ adrenergic receptor was identified as the best 3D experimental template for the homology modeling also for the $5-\mathrm{HT}_{6} \mathrm{R}$ (Sequence identity $=32 \%$ ). The high-resolution $(2.4 \mathrm{~A}$ ) crystal structure of the human $\beta_{2}$ adrenergic receptor ( $\left.\beta_{2} \mathrm{AR}\right)$-T4 lysozyme fusion protein bound to the carazolol (PDB: 2RH1) [29] was used as the 3D template. The alignment between the two sequences was manually optimized to avoid insertions and deletions in secondary structure elements. Disulfide bond: $\mathrm{Cys}_{99}-\mathrm{Cys}_{180}$ between the transmembrane helix 3 (TM3) and the extracellular loop (ECL2) was conserved. This alignment (Figure S2) was used as the basis for the homology modeling with the Modeller software [38]. The resulting model was then evaluated by methods like verify3D [39] and Eval23D [40].

The docking of the donecopride and $7, \mathbf{3 b}, \mathbf{1 2} \mathbf{b}$ compounds into the generated model was carried out with the GOLD program (v2020.2.0) [26,27] using the same procedure as for $5-\mathrm{HT}_{4} \mathrm{R}$. The binding site in the 5- $\mathrm{HT}_{6} \mathrm{R}$ model was defined as a $10 \AA$ sphere centered on the cysteine residue $\mathrm{Cys}_{110}$. A hydrogen bond constraint between positively ionizable amine ligand and OD atom of Asp 100 was also applied during the docking and the following amino acids were kept flexible: $\operatorname{Trp}_{102}, \mathrm{Asp}_{106}, \mathrm{Ser}_{193}, \mathrm{Thr}_{196}$, and $\operatorname{Trp}_{307}$.

\section{Conclusions}

In conclusion, we prepared two novel series of conformationally constrained donecopride analogs using a late stage functionalization process. The introduction of the novel pyrazole ring instead of the ketone linked reduces the ability of novel ligands to interact both with $\mathrm{AChE}$ and $5-\mathrm{HT}_{4} \mathrm{R}$. These results were confirmed thanks to our docking study. The replacement of the cyclohexyl moiety of donecopride with a $m$-tolyl group led, however, to a novel phenyl pyrazole $3 \mathbf{b}$ as a dual active compound toward AChE and 5-HT $R$. According to our docking studies, the introduction of a substituted benzyl moiety on the piperidine ring enhanced the ability of $\mathbf{3 b}$ to interact with $\mathrm{AChE}$ and $5-\mathrm{HT}_{6} \mathrm{R}$ active site thanks to stronger hydrophobic interactions. This preliminary result is of clear interest in the journey toward the identification of valuable pleiotropic compounds for the treatment of neurodegenerative diseases. Indeed, the simultaneous modulation of 5- $\mathrm{HT}_{6} \mathrm{R}$ and $\mathrm{AChE}$ could lead to an interesting synergistic effect in the treatment of $\mathrm{AD}$, as demonstrated with the use of idalopirdine and donepezil in the clinical trials. 
Based on these promising preliminary results, a future pharmacomodulation of $\mathbf{3 b}$ will be envisaged in order to increase its interaction with $5-\mathrm{HT}_{6} \mathrm{R}$ and with $\mathrm{AChE}$.

Supplementary Materials: The following data are available online. Including analytical spectrum of the compounds, superimposition of $\mathbf{7 , 1 2 b}$ and $\mathbf{3 b}$ with donecopride in AChE binding site and amino-acid sequences alignment of $5-\mathrm{HT}_{6} \mathrm{R}$ and human $\beta 2$-adrenergic receptor. Reference [41] is cited in the Supplementary Materials.

Author Contributions: Conceptualization, C.R. and P.D.; methodology, C.L., R.L., A.D., and J.S.d.O.S.; software, J.S.-d.O.S.; validation, C.R. and P.D.; writing-original draft preparation, C.R. and P.D.; writing-review and editing, C.L., J.S.-d.O.S., C.R. and P.D.; funding acquisition, C.R. and P.D. All authors have read and agreed to the published version of the manuscript.

Funding: This work was supported by funding from the Région Normandie (RIN GreenChem) and FEDER through the CERMN's analytical platform.

Institutional Review Board Statement: Not applicable.

Informed Consent Statement: Not applicable.

Data Availability Statement: The data presented in this study are available within the article and Supplementary Materials.

Acknowledgments: The present work was performed thanks to the generous computing resources provided by the CRIANN (Normandy, France). The authors gratefully acknowledge the European Community (FEDER) for the molecular modeling software.

Conflicts of Interest: The authors declare no conflict of interest.

Sample Availability: Samples of the compounds are available from the authors.

\section{References}

1. Cavalli, A.; Bolognesi, M.L.; Minarini, A.; Rosini, M.; Tumiatti, V.; Recanatini, M.; Melchiorre, C. Multi-target-Directed Ligands To Combat Neurodegenerative Diseases. J. Med. Chem. 2008, 51, 347-372. [CrossRef]

2. Albertini, C.; Salerno, A.; de Sena Murteira Pinheiro, P.; Bolognesi, M.L. From combinations to multitarget-directed ligands: A continuum in Alzheimer's disease polypharmacology. Med. Res. Rev. 2020, 1-28. [CrossRef]

3. Lalut, J.; Rochais, C.; Dallemagne, P. Multiple Ligands in Neurodegenerative Diseases. In Drug Selectivity-An Evolving Concept in Drug Discovery, Book Series "Methods and Principles in Medicinal Chemistry; Wiley-VCH Publishing House: Hoboken, NJ, USA, 2017; pp. 477-508.

4. Rodríguez-Soacha, D.A.; Scheiner, M.; Decker, M. Multi-target-directed-ligands acting as enzyme inhibitors and receptor ligands. Eur. J. Med. Chem. 2019, 180, 690-706. [CrossRef]

5. Lecoutey, C.; Hedou, D.; Freret, T.; Giannoni, P.; Gaven, F.; Since, M.; Bouet, V.; Ballandonne, C.; Corvaisier, S.; Fréon, A.M.; et al. Design of donecopride, a dual serotonin subtype 4 receptor agonist/acetylcholinesterase inhibitor with potential interest for Alzheimer's disease treatment. Proc. Natl. Acad. Sci. USA 2014, 111, E3825-E3830. [CrossRef]

6. Rochais, C.; Lecoutey, C.; Gaven, F.; Giannoni, P.; Hamidouche, K.; Hedou, D.; Dubost, E.; Genest, D.; Yahiaoui, S.; Freret, T.; et al. Novel Multitarget-Directed Ligands (MTDLs) with Acetylcholinesterase (AChE) Inhibitory and Serotonergic Subtype 4 Receptor (5-HT4R) Agonist Activities As Potential Agents against Alzheimer's Disease: The Design of Donecopride. J. Med. Chem. 2015, 58, 3172-3187. [CrossRef] [PubMed]

7. Rochais, C.; Lecoutey, C.; Hamidouche, K.; Giannoni, P.; Gaven, F.; Cem, E.; Mignani, S.; Baranger, K.; Freret, T.; Bockaert, J.; et al Donecopride, a Swiss army knife with potential against Alzheimer's disease. Br. J. Pharmacol. 2020, 177, 1988-2005. [CrossRef] [PubMed]

8. Cachard-Chastel, M.; Lezoualc'H, F.; Dewachter, I.; Deloménie, C.; Croes, S.; Devijver, H.; Langlois, M.; Van Leuven, F.; Sicsic, S.; Gardier, A.M. 5-HT4 receptor agonists increase sAPP $\alpha$ levels in the cortex and hippocampus of male C57BL/6j mice. Br. J. Pharmacol. 2007, 150, 883-892. [CrossRef]

9. Maillet, M.; Robert, S.J.; Cacquevel, M.; Gastineau, M.; Vivien, D.; Bertoglio, J.; Zugaza, J.L.; Fischmeister, R.; Lezoualc'H, F. Crosstalk between Rap1 and Rac regulates secretion of sAPP $\alpha$. Nat. Cell Biol. 2003, 5, 633-639. [CrossRef]

10. Egiannoni, P.; Egaven, F.; Bundel, D.E.; Ebaranger, K.; Emarchetti-Gauthier, E.; Roman, F.S.; Evaljent, E.; Emarin, P.; Ebockaert, J.; Erivera, S.; et al. Early administration of RS 67333, a specific 5-HT4 receptor agonist, prevents amyloidogenesis and behavioral deficits in the 5XFAD mouse model of Alzheimer's disease. Front. Aging Neurosci. 2013, 5, 96. [CrossRef]

11. Lalut, J.; Karila, D.; Dallemagne, P.; Rochais, C. Modulating 5-HT4and 5-HT6receptors in Alzheimer's disease treatment. Futur. Med. Chem. 2017, 9, 781-795. [CrossRef] 
12. Barnes, N.M.; Ahern, G.P.; Becamel, C.; Bockaert, J.; Camilleri, M.; Chaumont-Dubel, S.; Claeysen, S.; Cunningham, K.A.; Fone, K.C.; Gershon, M.; et al. International Union of Basic and Clinical Pharmacology. CX. Classification of Receptors for 5-hydroxytryptamine; Pharmacology and Function. Pharmacol. Rev. 2021, 73, 310-520. [CrossRef]

13. Karila, D.; Freret, T.; Bouet, V.; Boulouard, M.; Dallemagne, P.; Rochais, C. Therapeutic Potential of 5-HT6Receptor Agonists. J. Med. Chem. 2015, 58, 7901-7912. [CrossRef] [PubMed]

14. Benhamú, B.; Martín-Fontecha, M.; Vázquez-Villa, H.; Pardo, L.; López-Rodríguez, M.L. Serotonin 5-HT6Receptor Antagonists for the Treatment of Cognitive Deficiency in Alzheimer's Disease. J. Med. Chem. 2014, 57, 7160-7181. [CrossRef]

15. Arnt, J.; Bang-Andersen, B.; Grayson, B.; Bymaster, F.P.; Cohen, M.P.; Giethlen, B.; Kreilgaard, M.; McKinzie, D.L.; Neill, J.C.; Nielsen, S.M.; et al. Lu AE58054, a 5-HT6 antagonist, reverses cognitive impairment induced by subchronic phencyclidine in a novel object recognition test in rats. Int. J. Neuropsychopharmacol. 2010, 13, 1021-1033. [CrossRef]

16. Ferris, C.F.; Kulkarni, P.; Yee, J.R.; Nedelman, M.; De Jong, I.E.M. The Serotonin Receptor 6 Antagonist Idalopirdine and Acetylcholinesterase Inhibitor Donepezil Have Synergistic Effects on Brain Activity-A Functional MRI Study in the Awake Rat. Front. Pharmacol. 2017, 8, 279. [CrossRef] [PubMed]

17. Yahiaoui, S.; Hamidouche, K.; Ballandonne, C.; Davis, A.; Sopkova-de Oliveira Santos, J.; Freret, T.; Boulouard, M.; Rochais, C.; Dallemagne, P. Design, synthesis, and pharmacological evaluation of multitarget-directed ligands with both serotonergic subtype 4 receptor (5-HT4R) partial agonist and 5-HT6R antagonist activities, as potential treatment of Alzheimer's disease. Eur. J. Med. Chem. 2016, 121, 283-293. [CrossRef] [PubMed]

18. Hatat, B.; Yahiaoui, S.; Lecoutey, C.; Davis, A.; Freret, T.; Boulouard, M.; Claeysen, S.; Rochais, C.; Dallemagne, P. A Novel in vivo Anti-amnesic Agent, Specially Designed to Express Both Acetylcholinesterase (AChE) Inhibitory, Serotonergic Subtype 4 Receptor (5-HT4R) Agonist and Serotonergic Subtype 6 Receptor (5-HT6R) Inverse Agonist Activities, With a Potential Interest Against Alzheimer's Disease. Front. Aging Neurosci. 2019, 11, 148. [CrossRef]

19. Fang, Z.; Song, Y.; Zhan, P.; Zhang, Q.; Liu, X. Conformational restriction: An effective tactic in 'follow-on'-based drug discovery. Futur. Med. Chem. 2014, 6, 885-901. [CrossRef] [PubMed]

20. Lalut, J.; Payan, H.; Davis, A.; Lecoutey, C.; Legay, R.; Santos, J.S.-D.O.; Claeysen, S.; Dallemagne, P.; Rochais, C. Rational design of novel benzisoxazole derivatives with acetylcholinesterase inhibitory and serotoninergic 5-HT4 receptors activities for the treatment of Alzheimer's disease. Sci. Rep. 2020, 10, 3014. [CrossRef]

21. Bredereck, H.; Simchen, G.; Rebsdat, S.; Kantlehner, W.; Horn, P.; Wahl, R.; Hoffmann, H.; Grieshaber, P. Darstellung und Eigenschaften der Amidacetale und Aminalester. Chem. Ber. 1968, 101, 41-50. [CrossRef]

22. Beria, I.; Ballinari, D.; Bertrand, J.A.; Borghi, D.; Bossi, R.T.; Brasca, M.G.; Cappella, P.; Caruso, M.; Ceccarelli, W.; Ciavolella, A.; et al. Identification of 4,5-Dihydro-1H-pyrazolo[4,3-h]quinazoline Derivatives as a New Class of Orally and Selective Polo-Like Kinase 1 Inhibitors. J. Med. Chem. 2010, 53, 3532-3551. [CrossRef]

23. Genest, D.; Rochais, C.; Lecoutey, C.; Sopkova Oliveira Santos, J.S.; Ballandonne, C.; Butt-Gueulle, S.; Legay, R.; Since, M.; Dallemagne, P. Design, synthesis and biological evaluation of novel indano- and thiaindano-pyrazoles with potential interest for Alzheimer's disease. Med. Chem. Comm. 2013, 4, 925. [CrossRef]

24. Ellman, G.L.; Courtney, K.; Andres, V.; Featherstone, R.M. A new and rapid colorimetric determination of acetylcholinesterase activity. Biochem. Pharmacol. 1961, 7, 88-95. [CrossRef]

25. Cheung, J.; Rudolph, M.J.; Burshteyn, F.; Cassidy, M.S.; Gary, E.N.; Love, J.; Franklin, M.C.; Height, J.J. Structures of Human Acetylcholinesterase in Complex with Pharmacologically Important Ligands. J. Med. Chem. 2012, 55, 10282-10286. [CrossRef]

26. Jones, G.; Willett, P.; Glen, R.C. Molecular recognition of receptor sites using a genetic algorithm with a description of desolvation. J. Mol. Biol. 1995, 245, 43-53. [CrossRef]

27. Jones, G.; Willett, P.; Glen, R.C.; Leach, A.R.; Taylor, R. Development and validation of a genetic algorithm for flexible docking. J. Mol. Biol. 1997, 267, 727-748. [CrossRef]

28. Dubost, E.; Dumas, N.; Fossey, C.; Magnelli, R.; Butt-Gueulle, S.; Ballandonne, C.; Caignard, D.H.; Dulin, F.; Santos, J.S.D.-O.; Millet, P.; et al. Synthesis and Structure-Affinity Relationships of Selective High-Affinity 5-HT4 Receptor Antagonists: Application to the Design of New Potential Single Photon Emission Computed Tomography Tracers. J. Med. Chem. 2012, 55, $9693-9707$. [CrossRef] [PubMed]

29. Cherezov, V.; Rosenbaum, D.M.; Hanson, M.A.; Rasmussen, S.G.F.; Thian, F.S.; Kobilka, T.S.; Choi, H.-J.; Kuhn, P.; Weis, W.I.; Kobilka, B.K.; et al. High-Resolution Crystal Structure of an Engineered Human 2-Adrenergic G Protein-Coupled Receptor. Science 2007, 318, 1258-1265. [CrossRef]

30. Rivail, L.; Giner, M.; Gastineau, M.; Berthouze, M.; Soulier, J.-L.; Fischmeister, R.; Lezoualc'H, F.; Maigret, B.; Sicsic, S.; Berque-Bestel, I. New insights into the human 5-HT4 receptor binding site: Exploration of a hydrophobic pocket. Br. J. Pharmacol. 2004, 143, 361-370. [CrossRef] [PubMed]

31. Jain, E.; Bairoch, A.; Duvaud, S.; Phan, I.; Redaschi, N.; Suzek, B.E.; Martin, M.J.; McGarvey, P.; Gasteiger, E. Infrastructure for the life sciences: Design and implementation of the UniProt website. BMC Bioinform. 2009, 10, 1-19. [CrossRef]

32. Shia, J.; Blundell, T.L.; Mizuguchia, K. FUGUE: Sequence-structure homology recognition using environment-specific substitution tables and structure-dependent gap penalties11Edited by B. Honig. J. Mol. Biol. 2001, 310, 243-257. [CrossRef] [PubMed]

33. Zhou, H.; Zhou, Y. Fold recognition by combining sequence profiles derived from evolution and from depth-dependent structural alignment of fragments. Proteins Struct. Funct. Bioinform. 2004, 58, 321-328. [CrossRef] [PubMed] 
34. Altschul, S.F.; Madden, T.L.; Schäffer, A.A.; Zhang, J.; Zhang, Z.; Miller, W.; Lipman, D.J. Gapped BLAST and PSI-BLAST: A new generation of protein database search programs. Nucleic Acids Res. 1997, 25, 3389-3402. [CrossRef]

35. Schäaffer, A.A.; Aravind, L.; Madden, T.L.; Shavirin, S.; Spouge, J.L.; Wolf, Y.I.; Koonin, E.V.; Altschul, S.F. Improving the accuracy of PSI-BLAST protein database searches with composition-based statistics and other refinements. Nucleic Acids Res. 2001, 29, 2994-3005. [CrossRef] [PubMed]

36. Söding, J. Protein homology detection by HMM-HMM comparison. Bioinformatics 2004, 21, 951-960. [CrossRef]

37. Pons, J.-L.; Labesse, G. @TOME-2: A new pipeline for comparative modeling of protein-ligand complexes. Nucleic Acids Res. 2009, 37, W485-W491. [CrossRef] [PubMed]

38. Eswar, N.; Eramian, D.; Webb, B.; Shen, M.; Sali, A. Protein structure modeling with MODELLER. Methods Mol. Biol. 2008, 426, 145-159. [CrossRef]

39. Eisenberg, D.; Lüthy, R.; Bowie, J.U. VERIFY3D: Assessment of protein models with three-dimensional profiles. Methods Enzymol. 1997, 277, 396-404. [CrossRef]

40. Gracy, J.; Chiche, L.; Sallantin, J. Improved alignment of weakly homologous protein sequences using structural information. Protein Eng. Des. Sel. 1993, 6, 821-829. [CrossRef]

41. Robert, X.; Gouet, P. Deciphering key features in protein structures with the new ENDscript server. Nucl. Acids Res. 2014, 42, 320-324. [CrossRef] 